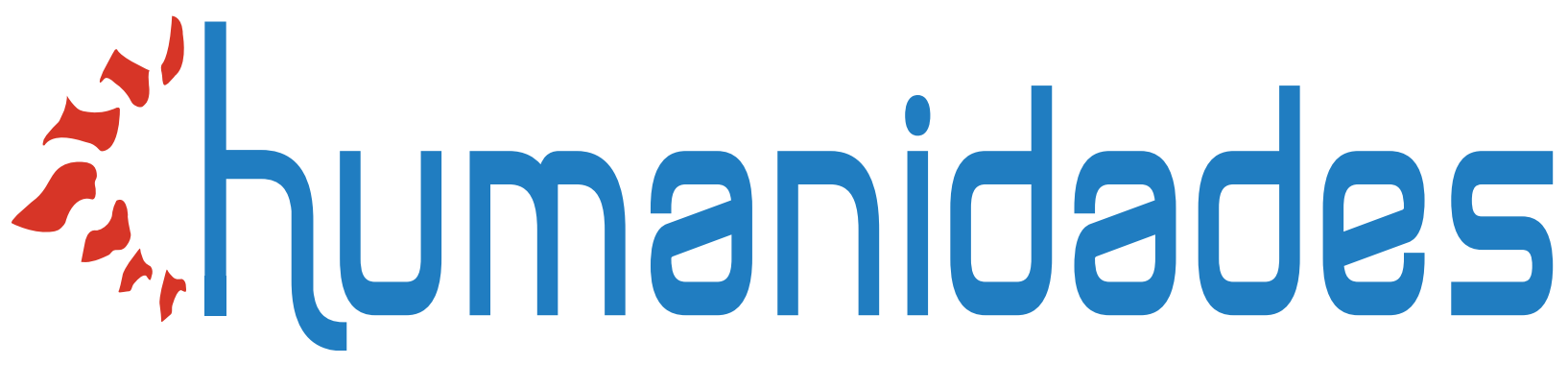

Ensayar desde el pensamiento retrospectivo: la multifotografía como metáfora del entrelazamiento entre ensayo, memoria y ficción en La invención de la soledad de Paul Auster

\author{
Eduardo Aguirre
}

DOI: https://doi.org/ I0.155 I7/h.v I0il .39985 https://revistas.ucr.ac.cr/index.php/humanidades/index

(c) $(\mathrm{B}) \Theta$

Universidad de Costa Rica 


\section{"humanidades}

Revista Humanidades

ISSN: 2215-3934

humanidades@ucr.ac.cr

Universidad de Costa Rica

Costa Rica

\section{Ensayar desde el pensamiento} retrospectivo: la multifotografía como metáfora del entrelazamiento entre ensayo, memoria y ficción en La invención de la soledad de Paul Auster ${ }^{1}$

Aguirre, Mtro. Eduardo

Ensayar desde el pensamiento retrospectivo: la multifotografía como metáfora del entrelazamiento entre ensayo, memoria y ficción en La invención de la soledad de Paul Auster ${ }^{1}$

Revista Humanidades, vol. 10, núm. 1, 2020

Universidad de Costa Rica, Costa Rica

Disponible en: http://www.redalyc.org/articulo.oa?id=498060395014

DOI: https://doi.org/10.15517/h.v10i1.39985

Todos los derechos reservados. Universidad de Costa Rica. Esta revista se encuentra licenciada con Creative Commons. Reconocimiento-NoComercial-SinObraDerivada 3.0 Costa Rica. Correo electrónico: humanidades@ucr.ac.cr/ Sitio web: http: //revistas.ucr.ac.cr/index.php/humanidades

Esta obra está bajo una Licencia Creative Commons Atribución-NoComercial-SinDerivar 3.0 Internacional. 


\title{
Ensayar desde el pensamiento retrospectivo: la multifotografía como metáfora del entrelazamiento entre ensayo, memoria y ficción en La invención de la soledad de Paul
} Auster $^{1}$

Essay Writing Through Retrospective Thinking: Multiphotography as a Metaphor of the Liaison between Essay, Memory and Fiction in Paul Auster's "Portrait of an Invisible Man"

Mtro. Eduardo Aguirre

Universidad de Guadalajara, México

DOI: https://doi.org/10.15517/h.v10i1.39985

Jesus.AguirreN@alumno.udg.mx

Redalyc: http://www.redalyc.org/articulo.oa?

(iD http://orcid.org/0000-0001-7496-6885

id $=498060395014$

Recepción: 14 Octubre 2019

Aprobación: 25 Noviembre 2019

\section{RESUMEN:}

El presente artículo tiene por objeto establecer un tipo de lazo entre ensayo, memoria y ficción. Intentaremos demostrar que su entrelazamiento no sucede únicamente porque la prosa se ficcionaliza puesto que el recuerdo es sospechoso y poco confiable (lugar común de la crítica), sino más bien porque quien ensaya desde la memoria mistifica su objeto de estudio, multiplicándolo como quien pone dos espejos frente a frente, presentando la imagen multiplicada bajo la apariencia de la vivencia personal. Para ello, en primer lugar, indagaremos la proximidad entre ensayo y memoir; posteriormente, daremos cuenta de la manera en que se activa la escritura ensayística a través del recuerdo difuso y la memoria reconstruida; finalmente, como evidencia de nuestra premisa, mostraremos cómo se lleva a cabo este hecho en "Retrato de un hombre invisible" del norteamericano Paul Auster.

Palabras ClaVE: Ensayo literario, Literatura de ficción, Forma y género literario, Literatura contemporánea.

\begin{abstract}
:
The purpose of this article is to establish a certain type of relationship between essay, memory and fiction. We will demonstrate that this particular combination doesn't happen exclusively because prose is fictionalized since the writer's memory is suspicious and unreliable (common place of criticism), that is to say that whoever engages in essayistic writing from memory tends to mystify its object of study, multiplying it as who puts two mirrors face to face, presenting the image multiplied under the appearance of personal experience. In order to do this, first we will inspect the proximity between essay and memoir's; afterwards, we will exhibit the way in which essay writing is activated through diffuse and reconstructed memory. In the end, as evidence to our premise, we will attest how this is done in "Portrait of an Invisible Man" by American writer Paul Auster.
\end{abstract}

KEYWORDS: Essays, Fiction, Literary forms and genres, Contemporary literature.

\section{INTRODUCCIÓN}

Las imágenes no viven. Sin embargo, me parece que teniendo este aparato, conviene inventar otro, que permita averiguar si las imágenes sienten y piensan (o, por lo menos, si tienen los pensamientos y las sensaciones que pasaron por los originales durante la exposición; es claro que la relación de sus conciencias (?) con estos pensamientos y sensaciones no podrá averiguarse.

La Invención de Morel, Adolfo Bioy Casares

En este artículo vamos a ocuparnos de la relación entre ensayo, memoria y ficción, mejor dicho, la manera en que la ensayística ficcional -fusión entre ensayo y ficción ${ }^{2}$ - se comporta cuando se acude a la memoria como recurso literario. La evidencia que mostraremos para esta premisa será un tipo de técnica fotográfica llamada multifotografía, aprovechada por el escritor norteamericano Paul Auster en "Retrato de un hombre 
invisible", primera parte del libro La invención de la soledad (2012). La multifotografía cobró cierto auge hacia finales del siglo XIX y las primeras décadas del XX. Empleada por ciertos artistas de vanguardia, dicha técnica consiste en sentar a la persona retratada frente a dos espejos en ángulos entre los 45 y los 180 grados, dependiendo de la angulación, el retratado se "multiplicaba" de tres a siete veces, de modo que el efecto producía distintas perspectivas de un solo objeto. El retrato que Paul Auster descubre es, en efecto, una multifotografía de Sam Auster, su padre, a partir de la cual sostendremos que Auster, además de estar llevando a cabo un duelo por escrito a través de un memoir, está articulando una metáfora en torno al fallecimiento de su padre mediante un ensayo que tiene por tópico principal la muerte. Esta especulación halla su justificación en el eco que dicha metáfora tiene en el trabajo de Marcel Duchamp, el cual Auster conocía, asunto que nos conduce a formular una suerte de armonía entre ambos.

Propondremos también que la lectura que hacemos del texto de Auster sirve para problematizar el entendimiento que tenemos del ensayo como escritura supuestamente no ficcional, así como para suscribir la beta imaginativa que caracteriza al memoir (por encima de la naturalista), misma que posibilita, por decirlo de alguna manera, la reconstrucción de la memoria. Por ello, antes de llegar a Paul Auster, serán necesarias dos paradas: la primera de ellas para bosquejar algunas nociones problemáticas del memoir como texto memorístico tal como se concibe actualmente, al menos desde cierto sector de la crítica anglosajona; la segunda, abordará la memoria difusa y el recuerdo reconstruido como posibilidad ensayística. No cabe duda que el texto de Paul Auster se presta para referirnos al texto mismo y al eco que, creemos, puede tener en la teoría literaria. No basta, desde luego, puntualizar dónde se encuentra el contubernio entre ensayo y ficción sino explicamos cómo es que dicho mecanismo de ilación se pone en marcha. Del mismo modo, a la inversa, conviene aprovechar el vuelo del análisis propuesto para comprobar, en la medida de lo posible, si hace tambalear uno que otro atavismo. En las líneas que siguen queremos probar que escribir por vía del recuerdo difuso, de entrada, es quizá la única manera de reconstruir la memoria y, en segundo lugar, el modo tan particular que tiene el ensayo de ir tras una pista así sea de un pasado inexistente, de averiguar los pormenores de una evocación que no se sabe real o imaginada -y asumir, por supuesto, la angustia derivada de dicha incertidumbre-, en conjunto con el escudriñamiento de lo que uno fue con lo que uno cree ser.

Para llevar a cabo dicho trabajo es preciso estipular la forma en que el pensamiento retrospectivo se activa en el ensayo y el memoir, sobre todo cuando se ha reconocido plenamente que la memoria es su materia de trabajo. En este sentido, procederemos, en primer lugar, explicando nociones generales del memoir como clase de texto literario, así como su proximidad con la escritura ensayística. Entenderemos el memoir como aquella clase de texto que acude a la reflexión retrospectiva para la reconstrucción de uno o varios episodios supuestamente biográficos. Veremos más adelante cuán problemática es la palabra biográfico, pues el memoir es un entrecruzamiento entre biografía, autobiografía, figuración yoica, narrativa y ensayo literario. Desenredar tal maraña no está, desde luego, en nuestro propósito, aquí nos encargaremos de plantear de qué manera existe un tratamiento ensayístico ficcional al paso del tiempo, es decir, cómo la experiencia va quedando atrás y lo único que pervive, a pesar de todo, es la tentativa por darle un significado tratado retrospectivamente. Las frágiles evocaciones al pasado se hacen desde una memoria poco confiable, desde un pensamiento retrospectivo que dentro de su misma narrativa es impreciso y dudoso, sobre todo, como lo mostraremos con Paul Auster, cuando se trata de la reconstrucción de la imagen de su padre una vez que este ha fallecido. No cabe duda de que uno de los tópicos más socorridos en el memoir es la infancia, principalmente la infancia en donde el padre es una cuenta pendiente. Así lo hizo Phillip Roth en Patrimonio (2007), así lo hizo también el inglés Christopher Hitchens en Hitch-22 (2011), del mismo modo lo hizo el maestro Julian Barnes en su afamado ensayo sobre la muerte Nada que temer (2010).

Por otra parte, comprenderemos el ensayo de Paul Auster -y, de cierta manera, el ensayo en general- fuera de la categoría absurda de la prosa sin ficción, es decir, asumiendo que la ficcionalidad está a menudo presente en los textos ensayísticos a través de diversas formas y diversos grados de inserción (fantasías, exageraciones, invenciones, dramatizaciones, improvisaciones, etc.). Expondremos que la noción de "doble perspectiva" 
establecida por Phillip Lopate es la ligadura entre ensayo, memoria y ficción. Aludiremos al cruce de opiniones que tuvieron Lopate y el escritor mexicano Luigi Amara, en el que se discute ese hábito del ensayista de observar su pasado a través de la imaginación. Cabe destacar que La invención de la soledad se escribe cuando el padre de Auster muere de manera repentina. Mientras organizaba los objetos que su padre había dejado (ropa, fotografías, cartas...), Auster no logra distinguir entre su padre y el que va configurándose mientras examina los objetos. En aras de solventar la laguna, el texto de Auster va componiéndose como un ensayo sobre la muerte, y es precisamente aquí donde encuentre sus mayores obstáculos referenciales. Comencemos, pues.

\section{El RECUERDo DifUSO Y LA MEMORIA RECONSTRUIDA: DEL ENSAYO AL MEMOIR Y VICEVERSA}

Los días aciagos que atravesamos se prestan para que la memoria se comporte como refugio, sobre todo a la luz de aquella moraleja tan visitada de que todo tiempo pasado fue mejor. No sorprende, por tanto, que la urgencia por acudir a la memoria en combinación con el hábito de poner al yo como espectáculo del otro, tenga por resultado la abundancia de textos biográficos y autobiográficos de las últimas décadas. La académica norteamericana Paula S. Fass (2006) ha llamado al memoir el subgénero contemporáneo por excelencia. "Podemos entenderlo en un primer momento como un comentario al tiempo transcurrido que visibiliza lo invisible, como una clase de escritura ideal para la fundación de uno mismo" (p.116). También como un texto estrictamente de carácter no ficcional (Schwartz, 1998), íntimo, emocional y casi siempre narrado por una instancia yoica reconocible con el autor. Desde luego, estas características poseen un carácter más bien ideal, pues al ser el memoir una clase de texto en el que confluyen otros más, su identidad genérica es difícil de precisar.

En este sentido, la crítica literaria, sobre todo en la vertiente anglosajona, sugiere constantemente que se le estipulen algunos acuerdos consensuados a modo de líneas restrictivas (Crum, 2015). El primero de ellos es que el memoir es el acto de dar testimonio sobre un pasado apremiante que demanda una significación actualizada. El segundo de ellos consiste en aceptar que el pasado tiende a ser sospechoso, motivo suficiente para que la ficción aflore de una u otra manera. El tercero y último reside, fundamentalmente, en el compromiso ético del escritor con respecto a si lo relatado es parte de un recuerdo genuino o alterado. A partir de estas tres pautas el debate se dispara en distintas direcciones, pero es la ficción y sus implicaciones lo que afecta y modifica los paradigmas mencionados. Decimos que es la ficción, pero nos referimos primordialmente al carácter no ficticio del memoir, que es una de las más grandes imposiciones a esta clase de textos.

Es preciso decir que dicha imposición concede cierta flexibilidad de acuerdo con los intereses que estén en juego, es decir, que se acepta que en el memoir quepa algo de ficción puesto que no todo puede ser recordado con certeza, pero lo inadmisible recae en el hecho de que contenga más ficción que hechos corroborados. Así, es altamente probable que en las memorias de Bob Dylan pasemos por alto la omisión de uno que otro desenfreno de finales de los setenta, pero sería imperdonable que en la memorias todavía no publicadas del expresidente mexicano Gustavo Díaz Ordaz se omita, mucho menos que se modifique, mejore o perfeccionen los sucesos del sesenta y ocho en provecho de su imagen. En ninguno de los dos casos la omisión deviene ficción, pero cuando el retoque entra en juego la incredulidad del lector se activa. La pregunta obligada, por ende, reside en si la experiencia que el que autor pone a nuestra consideración puede tomarse como una referencia fáctica o como pura invención novelizada.

Siendo el memoir un texto personalísimo de indagación profunda, de cuentas pendientes o de recuperación de un tiempo extraviado, su peso radica nuevamente en el viejo adagio ensayístico en torno la responsabilidad de quien escribe; en otras palabras, en anidar las dos máximas de Michel Montaigne: yo mismo soy la materia de mi libro, y este libro, lector, antes que otra cosa, es de buena fe. Recordemos que bajo estas dos premisas 
ensayísticas la crítica rutinaria ha anclado la obra al autor, en donde el empleo de la primera persona genera la impresión de que estamos frente a un autorretrato sincero. De ninguna forma esta expectativa es algo absurdo; en efecto, habrá quienes sí -y quizá sean la mayoría- cumplan a cabalidad una suerte de contrato ético entre lo sucedido y lo relatado. Con esto queremos decir que el imperativo no ficticio que se espera en los memoirs es de grado y en ocasiones dependerá de factores que quizá nada tengan que ver con estatutos literarios, y en otros se apreciará y celebrará en nombre de un aprovechamiento artístico bien logrado. No queda claro, por lo demás, cómo se lleva a cabo tal discernimiento. Podemos, desde luego, intuirlo -temperatura social, criterios editoriales, expectativas políticas, notabilidad de la figura pública, etcétera-, si bien saberlo no serviría de gran cosa. Vemos, entonces, que será complicado que el imperativo no ficticio subsista, sobre todo si a la lista de factores agregamos la fabulación imaginativa en complicidad con la memoria. Podríamos, si así lo quisiéramos, persistir en la beta argumentativa de lo vivido versus lo fabricado -asunto que nos retornaría a los paralelos miméticos de la realidad duplicada, es decir, al "proyecto descabellado de los cartógrafos" que mencionaba Baudrillard (1978)-, pero, si optamos, en cambio, por pensar que el memoir será lo que se quiera menos una imitación de la vida -mucho menos de la de alguien más, como es el caso de Paul Auster-, podremos acaso estar en condiciones de pautar un nuevo espectro de comprensión ensayística.

Un gran número de estudios fijan su atención en técnicas particulares de la ficción para extraer de ellas el alto o bajo grado de inventiva. La conclusión natural nos remite a un resultado cuantitativo que dictamina si la memoria puede ser confiable (reliable) con respecto a su contenido y, si como lo mencionábamos hace unos momentos, la materia o campo de estudio al cual se asocie carga consigo la incansable y justa petición del abandono de la demagogia en nombre de la verdad, veremos que el lado más ingenuo de la ficción, el de ser sinónimo de mentira o calumnia, persiste. Por esta razón, llegados a este punto, denunciar que tal o cual texto contiene un exceso de ficción ya no es suficiente, lo que toca es fijarnos en el resultado del simulacro elaborado y explicar, con algo de suerte, cómo funciona el aparato retórico que se ha llevado a cabo. Es este un lugar poco visitado por aquellos que teorizan sobre el ensayo, quienes continúan habitando la cómoda isla de estudiar al género exclusivamente por sus lindezas de contenido.

Es así, pues, que debido a la marcada inclinación por emplear la primera persona como instancia de enunciación y por su tendencia natural a examinar el significado de la experiencia, ensayo y memoir son dos escrituras cercanas entre sí. Una de las características que los mantienen próximos es que el memoir se parece al ensayo (o el ensayo al memoir) por lo problemático que resulta establecerles filiación genérica. Por una parte, desde la práctica editorial anglosajona, el memoir refiere a un subgénero literario con preferencia por la reminiscencia; por la otra, el mémoire, en su acepción francesa, se entiende como el acto de recordar o hacer memoria por escrito de forma breve, en donde la expectativa apunta a que el autor, también reconocible con el narrador del texto, presente su opinión sobre lo recordado, de modo que, cuando se acude a la memoria, sobrevuele la sensación de que el escritor está, por decirlo de alguna manera, ensayando. La misma Paula S. Fass, por ejemplo, piensa que la diferencia principal entre la memoria y el resto de las formas literarias que acuden a la memoria es de alcance: mientras que la literatura aspira a una verdad de amplitud universal, el memoir se enfoca en extraer la verdad de un episodio particular (la infancia, pongamos por caso) (Fass, 2006).

El problema es que la memoria no puede someterse a juicio. La memoria no tiene constatación empírica. Lo que queda, en el mejor de los casos, es la buena fe, pero no en el sentido del imperativo de verdad, sino buena fe en cuanto a la búsqueda de la verdad solamente como garantía de intento (Weinberg, 2012). Es así como podemos hablar del memoir como una forma en la que se nos presenta la ensayística ficcional, en el sentido de estar frente a una escritura que reflexiona de forma retrospectiva, en donde su principal recurso es la memoria que linda con la imaginación y donde nos encontrarnos nuevamente con retoques, modificaciones, dramatizaciones, exageraciones, ocultamientos, revelaciones, camuflajes y, ahora con Paul Auster, con un juego de perspectivas, una imagen multiplicada, a saber, la del padre. El memoir de Paul Auster -mejor dicho: los resultados a los que arriba Paul Auster a través de la reconstrucción de su padre- es la prueba de que cuando la laguna biográfica se completa con imaginación, el resultado no puede ser otro que el de una posibilidad 
latente, no de lo que fue ni de lo que pudo haber sido -que no tendríamos manera de corroborar ( $\mathrm{y}$ a todo esto, ¿̨por qué y para qué querríamos hacerlo?)-, sino de lo que es ahora y que se recuerda por escrito. Es esta, precisamente, la memoria fabricada. Es esta la idea que se ensaya.

\section{ReVIVIR LA MEMORIA: LA DOBLE PERSPECTIVA DEL MEMOIR COMO ESCRITURA ENSAYÍSTICA}

Antes de llevar a cabo un análisis detenido de Paul Auster, vale la pena tener en cuenta dos antecedentes relativamente recientes. Las armonías entre ensayo, memoria e imaginación cuentan con un cruce de opiniones entre el norteamericano Phillip Lopate y el mexicano Luigi Amara. En Reflection and Retrospection: a pedagogic mystery story (2005) Phillip Lopate recalca la proximidad entre ensayo y memoir, en tanto que ambos son escrituras subjetivas representadas por la primera persona del singular, el "truco", como él mismo lo llamaba, "consiste en establecer una doble perspectiva: por una parte, las confusiones y malentendidos de la voz que narra; por la otra, la sabiduría sofisticada de quien lo mira todo en retrospectiva" (p. 143). Para Lopate, sea en una autobiografía, memoir o ensayo personal, analizar "el significado de la experiencia" se lleva a cabo a través de estas dos formas de observación; es decir, por un lado se encuentra la voz narrativa que acude al pasado en aras de reconstruir, digamos, un episodio de la infancia, en donde tal reconstrucción irá encontrándose con malentendidos y confusiones subsanados a través de la memoria; del otro, el escritor que activa una sabiduría plena, madura, capaz de proveernos de material biográfico y dotarlo de un sentido renovado, misma que nos guiará, explicará, resumirá e interpretará los hechos recordados (Lopate, 2005).

Destaquemos de entrada que Lopate contempla al ensayo como una clase de texto en donde se pone en marcha la doble perspectiva, es decir, como un tipo de escritura en la que el autor está separado de su instancia de enunciación. Lopate (2005) lo explica de la siguiente manera: cuando echamos mano de la memoria, la voz narrativa y el protagonista son dos criaturas distintas,

y por lo tanto el narrador sabría cosas que el Yo-personaje no; toda la no ficción es una configuración imaginaria de hechos en una narrativa determinada, que distorsiona o miente siendo altamente selectiva y su objetivo es alcanzar un sentido de verdad literaria, no literal ${ }^{3}$ (pp. 145-146).

No está de sobra especificar que Lopate sitúa en el lado de las confusiones y malentendidos al protagonista o Yo-Personaje y del lado de la sabiduría sofisticada a la voz narrativa o narrador. Lo que no parece quedar claro es si aquello de alcanzar la verdad literaria (y no literal) también se somete a la división anterior, es decir, si toda la no ficción es una configuración imaginaria de hechos, ¿es acaso responsable el Yo-protagonista -que está confundido y tiende a malinterpretar- de mentir y distorsionar selectivamente? ¿O es la voz narrativa sabia y sofisticada- la que reordena el material y alcanza, por fin, alguna clase de verdad? Resulta significativo igualmente que Lopate adjudique dichas acciones -mentir, configurar, imaginar y buscar la verdad literariaa la escritura no ficcional, cuando, en realidad, cada una de ellas podrían (y lo hacen) operar en provecho de la ficción.

Estas interpelaciones localizan algo de luz en otro de sus libros, To show and tell: The Craft of Literary Nonfiction (2013), en donde se apunta lo siguiente:

Recientemente, en una visita a México, tuve una conversación con dos ensayistas mexicanos jóvenes, brillantes, filosóficamente entrenados, en torno a la naturaleza del ensayo. Ellos sostenían que, al menos el ensayo personal, debe ser clasificado como ficción (porque el Yo narrador es una construcción, porque la memoria no es confiable y se apoya en la imaginación para llenar los espacios vacíos, y porque la gran mayoría de las aserciones dentro de un ensayo personal no pueden ser ni probadas ni demostradas como verdaderas). [...] Pero yo sostenía -apunta Lopate-la idea de que la no ficción, incluyendo los ensayos personales, tienen una relación con la realidad factual y con el testimonio yoico que lo hace fundamentalmente diferentes de la ficción ${ }^{4}$ (Lopate, 2013, p. 78). 
Al menos uno de los dos ensayistas aludidos es Luigi Amara, tal como el propio Lopate lo ha dado a entender en la entrevista que Naief Yehya (2015) le hizo para la revista Letras Libres; la otra es probablemente Vivian Abenshushan. El hecho de que Lopate aluda a Luigi Amara no es casualidad; el mexicano es un autor que ha mostrado cómo queda en entredicho aquella certeza de que el ensayo es un medio para las ideas. Es de sobra conocido también que Luigi Amara ha propuesto en reiteradas ocasiones ${ }^{5}$ que el ensayo personal debería clasificarse como prosa ficcional (es decir: todo ensayo que tiente, indague, pasee sin destino, se pierda, vuelva y revuelva lo pensado -o sea toda exploración ensayística que compara su experiencia con el mundo, que es, en otras palabras, el ensayo comprendido bajo las coordenadas de Michel de Montaigne-, debería entenderse como ficción), y toda aquella escritura ensayística que no se ajuste a estos amarres -el paper académico, los trabajos divulgativos que abogan por la formalidad, los ensayos impersonales, la prosa mecanizada, el artículo por encargo, etc.- deberían agruparse, por obligación, en la non fiction y, por tanto, colocarse fuera del espectro de la literatura como arte ${ }^{6}$.

Conviene resaltar las propiedades que Luigi Amara confiere al ensayo de acuerdo con la cita de Phillip Lopate: si la memoria se apoya en la imaginación para llenar espacios vacíos y si dichos espacios no pueden ser ni probados ni demostrados como verdaderos, la memoria no es un recurso confiable (unreliable). Además, si agregamos que en libros de su autoría como Los disidentes del universo (2013) y La escuela del aburrimiento (2014) el yo es una invención neurótica, una construcción subjetiva, una fábula que se cuenta un sujeto a sí mismo, y la primera persona del singular no es alguien sino un lugar, caemos en cuenta cómo el ensayo se acerca más a una obra de creación que a un instrumento de difusión erudita (González, 2019).

Para Lopate, por otra parte -y podemos constatarlo en libros de talante más lírico como Contra la alegría de vivir (2008) y Retrato de mi cuerpo (2010)-, el estilo de ensayo personal que despliega tiene una relación directa con una realidad factual, y el dispositivo yoico, a manera de testimonio, enfatiza ciertos elementos de su personalidad. En la entrevista que le hizo Naief Yehya (2015), Lopate llama a los ensayistas escritores de no ficción. A pesar de que él mismo acepte el empleo técnicas de la ficción (uso de personajes, arcos narrativos, diálogos y escenas), ello no representa que en su trabajo literario se esté inventando algo. Cuando Lopate asevera que cuenta "las cosas como sucedieron" se refiere a que no todo ensayo personal, aunque linde con la ficción, es prosa ficcional, pues el problema es "cambiar o distorsionar lo que sabes que es real" (párr. 3). En el mismo tenor, Lopate sostiene que no se tiene por qué fingir que se sabe lo que no se sabe, si la libertad de fantasear ha sido una de las más grandes libertades del ensayo desde Montaigne. Para Lopate (2015), el escritor de no ficción, que es el lugar al que pertenece el ensayo personal, le es permitido la fantasía y la imaginación, siempre y cuando pueda detectarse que así se está haciendo:

Ya sabemos -sentencia Lopate- que las memorias distorsionan la historia, que cualquier tipo de relato sobre los hechos va a tener algún elemento subjetivo. Eso lo sabemos. Pero me parece que el escritor de no ficción, el ensayista personal, siempre trata de acercarse a la verdad y no sólo a la verdad literaria, sino a la verdad literal (párr. 4).

Es curioso advertir, sin embargo, que mencione nuevamente los términos verdad literaria y verdad literal, lo cuales ahora ha invertido. Recordemos que en Reflection and Retrospection, diez años antes, el escritor de memorias, que se parece al ensayista, aspirará a la verdad literaria, no a la literal; y ahora, diez años después, la mirada está puesta en la verdad literal, no literaria. ¿Cambió Lopate de parecer? No necesariamente. La inversión del orden de los términos -que, por otra parte, seguimos sin saber con exactitud a qué refieren- es un indicador de que pertenecen tanto a la ficción como a la no ficción, y que el uso de técnicas, artilugios o mecanismos ficcionales serán pertinentes a medida que así lo requiera la memoria. Asimismo, la tensión entre la ficción y la responsabilidad de apegarse a los hechos, tanto en el ensayo como en el memoir, reside en el uso o abuso de la misma, por ejemplo, menciona Lopate en la entrevista: "decir que naciste en 1946 cuando en realidad eres del cuarenta y tres".

Lo que en principio juzgaríamos como dos posturas irreconciliables va diluyéndose tan pronto caemos en cuenta de que ambos han llegado al mismo punto por caminos distintos. Lo que está detrás de la insistencia 
por situar al ensayo de un lado o del otro es la invocación inevitable de la tradición que le precede a cada uno, que al final del día parece ser prácticamente la misma. Si nos dejamos de ánimos clasificatorios -que la resistencia hacia la hibridación genérica actual hace imposible- lo que queda es el análisis del significado de la experiencia, que tanto para Amara como para Lopate es la vía para situarse como parte de ese largo linaje de autores expertos en el despliegue de la primera persona (Montaigne, Séneca, Hazlitt, Thoreau, Woolf, Chesterton...) (Yehya, 2015). El instante de conciliación de ambos, por ende, radica precisamente en el uso de la especulación como motor de la experiencia, en donde la especulación, a su vez, es una forma de la ficción, es el estado permanente del pensamiento retrospectivo.

Más allá de que el uso o abuso de la ficción altere la identidad genérica de un escrito memorístico, lo que está en juego, y que muchas veces queda de lado, es la imagen que se confecciona en torno al objeto de estudio. La imagen representada es, desde luego, una reconstrucción de la que sólo se tiene una idea vaga; cuando la distinción no es clara, cuando el paso del tiempo ha hecho imposible la distinción de los dos polos, "ahí es donde comienza la simulación" (Baudrillard, 1978, p. 64). No hay ni padre original ni ficticio, ni padre más o menos verdadero ni más o menos falso, pues en la simulación, que es donde ubicamos la ensayística ficcional, el supuesto modelo de verdad, como diría Deleuze, queda cancelado. Lo que queda, como sucedía con el fugitivo de La invención de Morel, es la repetición atestiguada de uno o varios episodios que obtienen su sentido exclusivamente a través de la reconstrucción especulativa.

\title{
3. La inQuietud inNombrable: EL ESPECtro Del PADRE EN "Retrato DE UN hombre invisible” de Paul Auster.
}

\begin{abstract}
Temo ser como mi padre, sentado en una silla junto a su cama de hospital, que me reprende con una ira nada habitual en él-«Dijiste que vendrias ayer»-, antes de comprender por mi expresión apurada que era él el que se habia equivocado de fecha. Nada que temer, Julian Barnes.
\end{abstract}

En Hitch-22. Confesiones y Contradicciones (2013), las memorias del escritor, periodista y crítico literario Christopher Hitchens se registra la siguiente anécdota: hacia 1977, en su paso por Buenos Aires, ciudad que visitaba, entre otros asuntos, para encontrarse un par de días con Jorge Luis Borges, el inglés relata que Borges -un Borges enclaustrado, prácticamente ciego y con una necesidad manifiesta de compañía- le ofreció un regalo a cambio de extender su estadía unas horas más. Frente a la protesta natural de Hitchens-regalo suficiente era, dice el autor, el privilegio de haber convivido en su casa-, Borges pidió entonces que atendiera unos versos bajo la promesa de que jamás fuera a olvidarlos:

¿Qué hombre no se ha inclinado a velar el sueño de su hijo, para meditar cómo mirará ese rostro el suyo cuando esté frío, o ha pensado, mientras su propia madre le besa los ojos, en cómo sería su beso cuando su padre la cortejaba? (Hitchens, 2013, p. 239).

Los versos, según Hitchens, pertenecen al soneto XXIX del poema "Inclusividad" de Dante Gabriel Rossetti, pero más que la procedencia, como él mismo lo declara, fue la idea que contenían, que desde que se convirtió en padre han vuelto a él más de una vez sin el más mínimo esfuerzo (Hitchens, 2013). Importa subrayar aquí el proceso interno de los versos, el cual consiste en el bucle temporal de miradas instituido, el mismo que revela magistralmente la transitoriedad paternal hijo-padre y padre-hijo, el mismo que constituye una forma de entender el por qué, apenas en la segunda página de sus memorias, Hitchens puede escribir algo como lo que sigue: "El placer ocasional del paso de los años -mirar hacia atrás y reflexionar sobre lo lejos que ha llegado uno- es rápidamente modificado por la idea que surge inmediatamente después, sobre el relativo poco tiempo que queda." (p. 19). Notaremos que los versos de Rossetti y las palabras de Hitchens comparten una estrategia de formulación: el padre vela el sueño del hijo, mientras se pregunta por el instante en que el hijo velará el suyo, que indudablemente apunta hacia el momento de su entierro. La relación filial no tiene 
fin: "yo -dice el padre-, ya no seré, pero mi hijo seguirá siendo" (Godínez, 2015, párr. 43). En ambos casos se ha abierto "la brecha de la esperanza" (párr. 43) a través del acto de mirar hacia atrás y reflexionar sobre lo lejos que ha llegado uno (a lo que Hitchens se refiere como el placer ocasional del paso de los años), para de inmediato sugerir la noción del tiempo finito, que resurgirá tan pronto el hijo, ahora padre, caiga en cuenta del relativo poco tiempo que queda.

Este vaivén especulativo que, vamos diciéndolo de una vez, se comporta a modo de premonición, encuentra cierto eco en un pasaje de Patrimonio (2007) del norteamericano Philip Roth, libro escrito durante la agonía del cáncer de su padre. Cierta ocasión en que lo ayudaba a darse un baño -el tumor cerebral había limitado ya prácticamente toda su motricidad-, mientras lo observaba desvestirse, Roth recuerda haberle visto el pene, dice el autor "la única parte de su cuerpo en que no se revelaba la vejez" (p. 176). Tras una serie de reflexiones breves sobre su tamaño, grosor y funcionamiento -Roth celebraba el placer que acaso pudo haberle propiciado a su madre-, la impresión del cuerpo desvalido del padre, en conjunto con la falta de decoro propia de la profesión del escritor (que el mismo Roth confiesa cuando la enfermedad representó la ocasión de un libro en potencia), propició lo que seguramente es el mito fundacional del padre como cuenta pendiente: "Tengo que recordarlo todo con precisión, para poder recrear en mi mente al padre que me creó, cuando él ya no esté" (p. 176). En esta "responsabilidad excesiva e irrenunciable" el hijo no puede impedir que el padre muera, pero tampoco admitirá que su padre desaparezca (Godínez, 2015). No es casualidad, entonces, que en la última página del libro, a seis semanas de haber fallecido el padre, este se le aparezca en sueños con una inconformidad: la ropa que Roth le había elegido para el entierro, y que es con la que pasaría la eternidad, no había sido de su agrado. Patrimonio concluye bajo la firme convicción de que el reclamo es la prueba de que, incluso muerto, su padre seguirá siendo un espectro en permanente juicio de sus acciones y el hijo un hombre con conciencia de niño. A esta reflexión Phillip Roth agrega lo que a la postre sería una de las máximas más celebradas de su trayectoria: No hay que olvidar nada.

No es azaroso, por tanto, que Paul Auster abra "Retrato de un hombre invisible" (2012) con apuro por iniciar el duelo: "mi padre ya no está, y si no hago algo de prisa, su vida entera se desvanecerá con él” (p. 12), ni tampoco que, párrafos después, diga que "Si cuando estaba vivo no hice otra cosa que buscarlo, intentar encontrar al padre que no estaba, ahora que está muerto siento que debo seguir con esa búsqueda” (p. 14), mucho menos que cierre preguntándose qué pasará cuando Daniel, su hijo, lea esas páginas (p. 101). Con los precedentes suscritos líneas arriba -es decir: la premonición de que el paso de los años apunta hacia la irreductible certeza de nuestra mortalidad, y que antes de que dicho momento llegue uno carga con la petición incesante de recordarlo todo-, el padre fallecido, o en tránsito hacia la muerte, tiene por finalidad un ajuste de cuentas. $\mathrm{Si}$, como parece suceder con la gran mayoría de los textos memorísticos, la evocación, antes que otra cosa, es el acto de reconstrucción de uno mismo, "Retrato de un hombre invisible" presenta una ligera variación, a saber: cuando un hombre muere a causa de una larga enfermedad es probable que se acepte con resignación, incluso que se achaque al destino, pero cuando un hombre muere sin causa aparente, cuando un hombre muere "simplemente por ser hombre" (p. 11), la escritura adopta la forma de un ensayo que tiene como tópico la muerte (que es precisamente el motivo de sus principales obstáculos). Es de suponerse, entonces, que la verdad imaginativa, como decía Julian Barnes, se halle en oposición a una verdad naturalista, lo que equivale a decir que tal ejercicio contiene en sí mismo sus oposiciones, contradicciones y su carácter insoluble (Barnes, 2010). Esto significa que la reconstrucción del padre, al menos en lo que concierne a Paul Auster, no se ocupe tanto de hacer con la sombra del padre una figuración propia -que es, parece ser, el ejercicio por excelencia de la autoficción-, sino de llevar a cabo una indagación del acto de hablar sobre otra persona y saber, en el proceso mismo de la escritura, si tal vanidad es siquiera posible. Puesto que ambos son proyectos inasibles -el otro y la muerte generan más preguntas que respuestas- la reflexión que acaso pueda propiciarse nos conduce irremediablemente a la desfiguración del objeto evocado. 


\subsection{La memoria multiplicada: retrato de Sam Auster}

Cuando uno se pinta a sí mismo, tomando la expresión de Montaigne, la memoria es de primera mano (lo cual no significa, desde luego, estar libre de malentendidos); pero cuando el retrato es de alguien más, como si de un encargo se tratara y cuando la idea que se tiene es más bien vaga -o, aún peor: cuando todo lo que se sabe no es en absoluto compatible con la persona retratada-, cada trazo debe inventarse al paso. Es así como en "Retrato de un hombre invisible" (2012) -un libro escrito "con fascinación obsesiva", menciona Auster (p. 23)- la indagación se emprenda a partir de que el autor decide enfrentarse a las pertenencias del padre fallecido. Frente a la sospecha de que las fotografías pudieran proporcionarle una verdad secreta -llenar lagunas, confirmar impresiones-, el hecho de que la gran mayoría le resultaran desconocidas animaba no solo el deseo de contemplarlas, también la sensación de un acceso antes restringido. Si en un principio la expectativa radicaba en forjar un recuerdo firme del padre a partir de sus rastros, a medida que "una cosa evoca a otra y a esta última otra más" (p. 50), la acumulación de detalles resulta contraproducente. Es en este sentido, tenemos que el principal atributo del padre es la invisibilidad, como si entre más escrupulosa y pormenorizada fuera la minucia, más abierto e indeterminado es el recuerdo de Auster. De ahí que la sensación de no llegar a ninguna parte vaya junto con la de estar escribiendo "sobre dos o tres personas diferentes, distintas entre sí, cada una en contradicción con las otras" (p. 91).

Conviene, llegados a este punto, hacer mención de la fotografía en la edición de Seix Barral. La portada del libro muestra a cinco hombres sentados en una mesa, todos con un ligero parentesco, todos mirando en direcciones distintas (ver Figura 1). Avanzada la lectura nos enteramos que en la fotografía no son cinco hombres diferentes sino uno sólo, Sam Auster, y que debido a un truco fotográfico la imagen se multiplica.

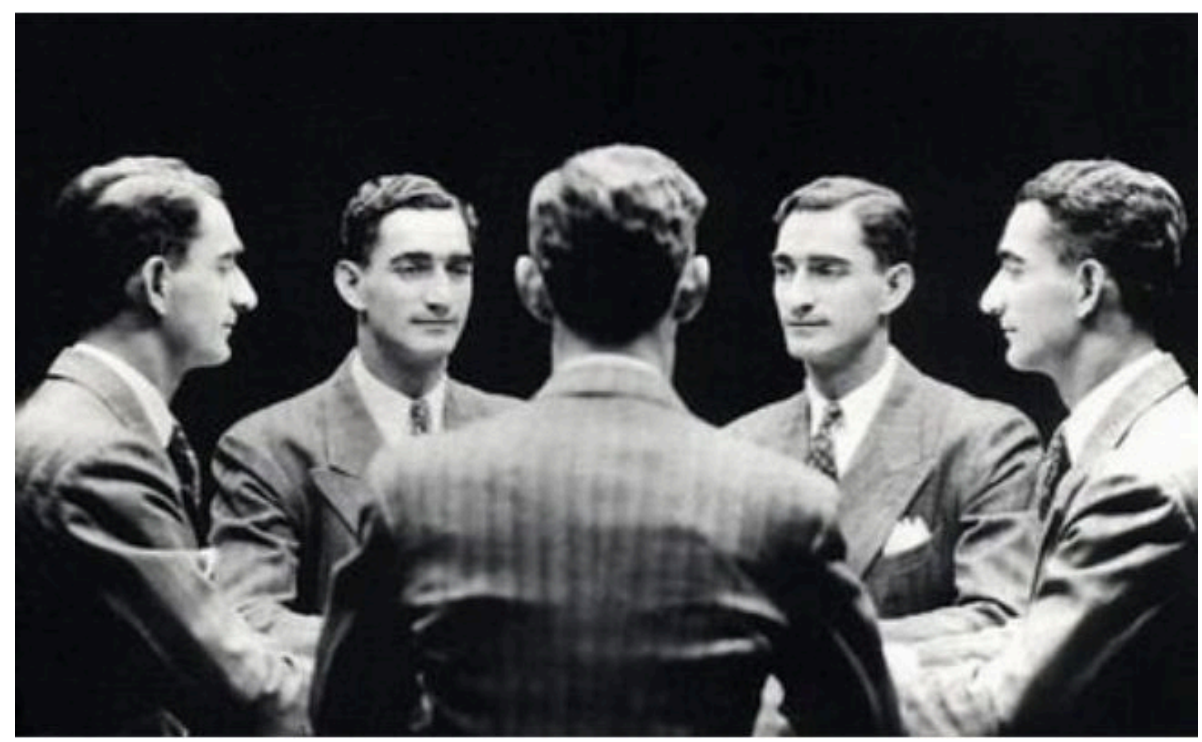

FIGURA 1.

Retrato de Sam Auster en portada de la edición de Seix Barral

Mientras hurgaba en las pertenencias de su padre, Auster encuentra esta fotografía tomada en un estudio de Atlantic City hace aproximadamente cuarenta años:

Por la penumbra que los rodea y la total inmovilidad de sus poses, pareciera que se han reunido para llevar a cabo una sesión de espiritismo. Pero luego, cuando uno estudia detenidamente la fotografía, advierte que se trata siempre del mismo hombre. La sesión de espiritismo se vuelve real y como si él hubiera asistido sólo para invocarse a sí mismo, para traerse de vuelta del reino de los muertos; como si multiplicándose a sí mismo hubiera desaparecido de forma accidental. Hay cinco imágenes de él, y sin embargo, la naturaleza de la fotografía no permite el contacto visual entre sus varios yoes. Cada uno de ellos está 
condenado a seguir con la vista fija en el espacio, como si lo observaran los demás, pero sin ver nada, incapaz de ver nunca nada. Es una fotografía de la muerte, el retrato de un hombre invisible (Auster, 2012, pp. 48-49).

El retrato de Sam Auster presenta un curioso truco de espejos conocido como foto multígrafa, retrato múltiple o multifotografía. Irwin Reichstein (2007) nos dice que esta técnica fue empleada durante el apogeo de los estudios fotográficos de finales del siglo XIX, principalmente, como una novedad artística. Consistía en sentar a la persona fotografiada en medio de dos espejos, uno a lado del otro, con ángulos variados entre los 45 y los 180 grados; dependiendo la angulación, el reflejo de los espejos producía de tres a siete retratos en hasta cuatro o cinco poses distintas, todo por el precio de una (ver Figuras 2 a 7$)^{7}$. De acuerdo con Reichstein, aunque la técnica gozó de cierta popularidad en fotógrafos amateurs y con algunos artistas de vanguardia, el truco perdió notoriedad hasta relegarse a suvenires de malecón. No obstante, existen registros no solo de fotografías múltiples en países como Italia, Argentina, Polonia, Estados Unidos, Rusia y Nueva Zelanda entre 1893 -supuesto año de creación- y hasta avanzada la tercera década del siglo XX, también los hay en libros y revistas especializadas tanto en ciencia como en arte fotográfico que mencionan la multifotografía como invención, moda o técnica fugaz (Reichstein, 2007).

La edición de 1931 de Photographic Amusements a cargo de Walter Woodbury, originalmente publicada en 1896, registra que la foto multígrafa había tomado un nuevo impulso (citado en Reichstein, 2007). Paul Auster descubre la fotografía en 1979, la que dice que tuvo que haber sido tomada cuarenta años antes, es decir, a finales de los años treinta, coincidiendo con lo que asevera Woodbury. Desconocemos quién fue el autor, pero sabemos que fue tomada en un estudio fotográfico de Atlantic City, ciudad famosa, dicho sea de paso, por su malecón a no más de dos horas de Newark, Nueva Jersey, lugar de residencia de la familia Auster. Desconocemos también la intención -bien pudo haber sido el resultado de una excursión de fin de semana o un proyecto personal desconocido, como se anota en el ensayo-, pero es por demás sensato conjeturar que la fotografía presume al menos un poco de planeación.

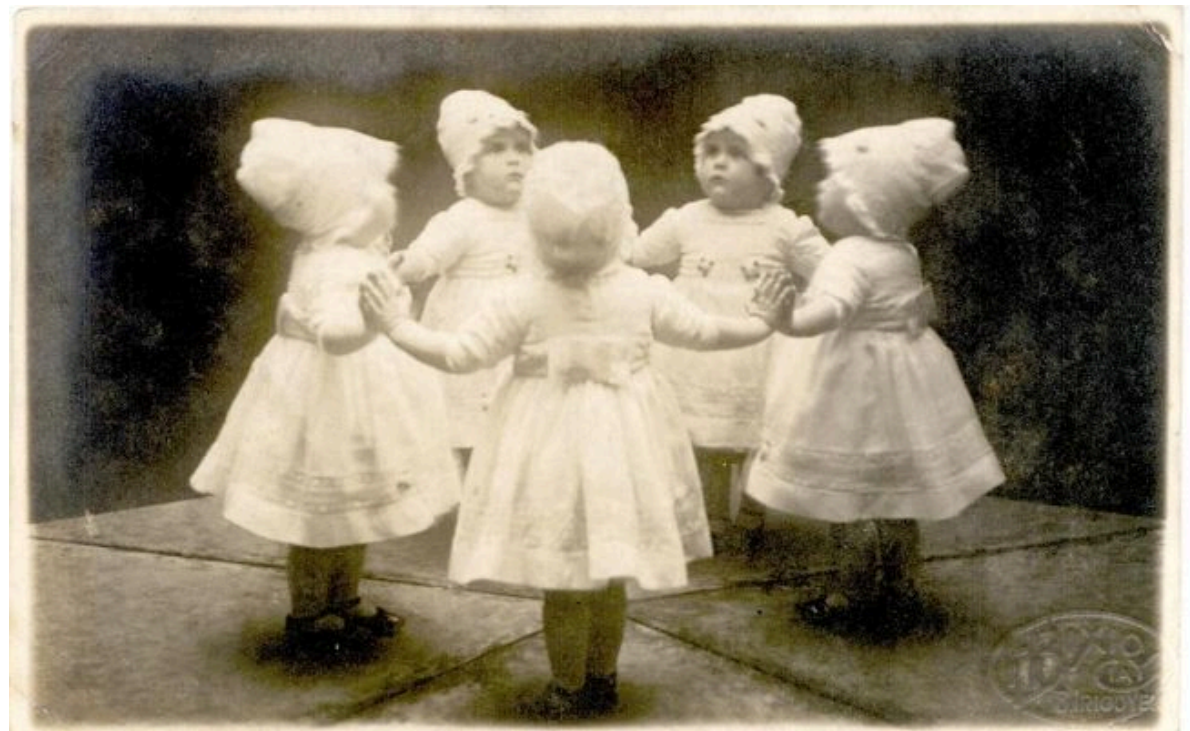

FIGURA 2.

Fotografía de Florencio Bixio y Cia. (Buenos Aires, s/a).

Colección Heinz-Werner, Lawo 


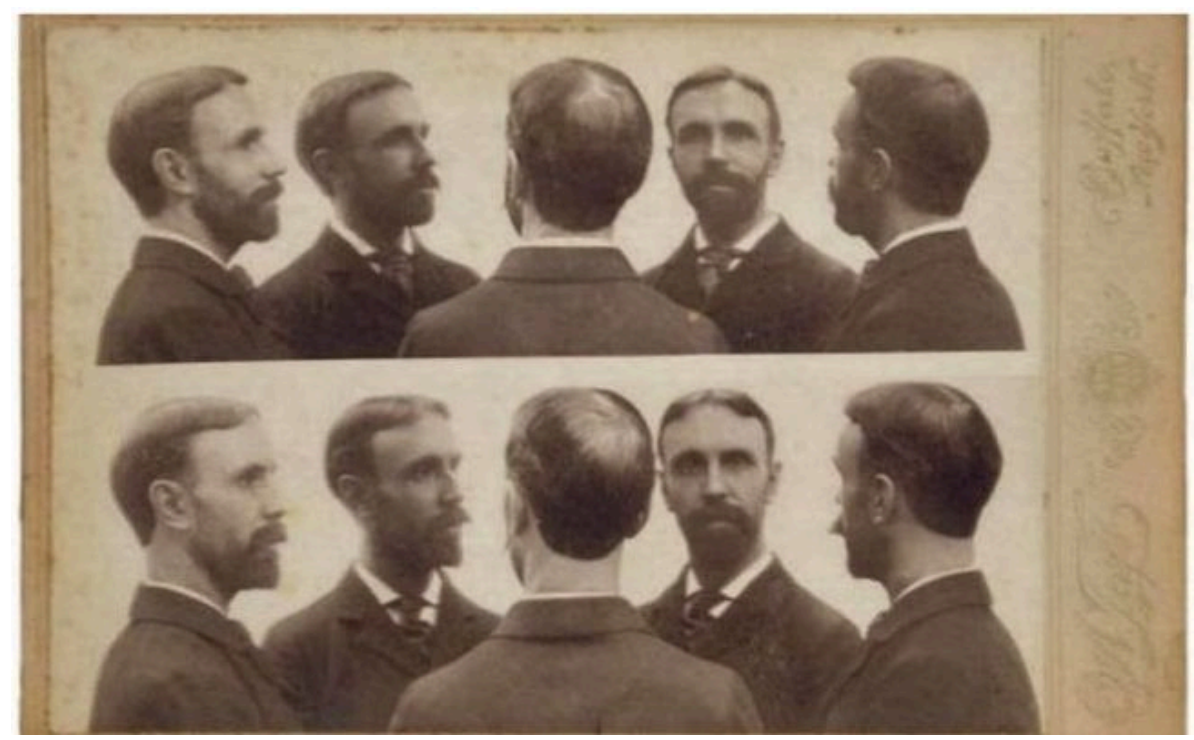

FIGURA 3.

Fotografía de Otis A. Taft (Buffalo, NY, 1896). "Multiple view portrait of an unidentified man". Cortesía de la Librería Schlesinger

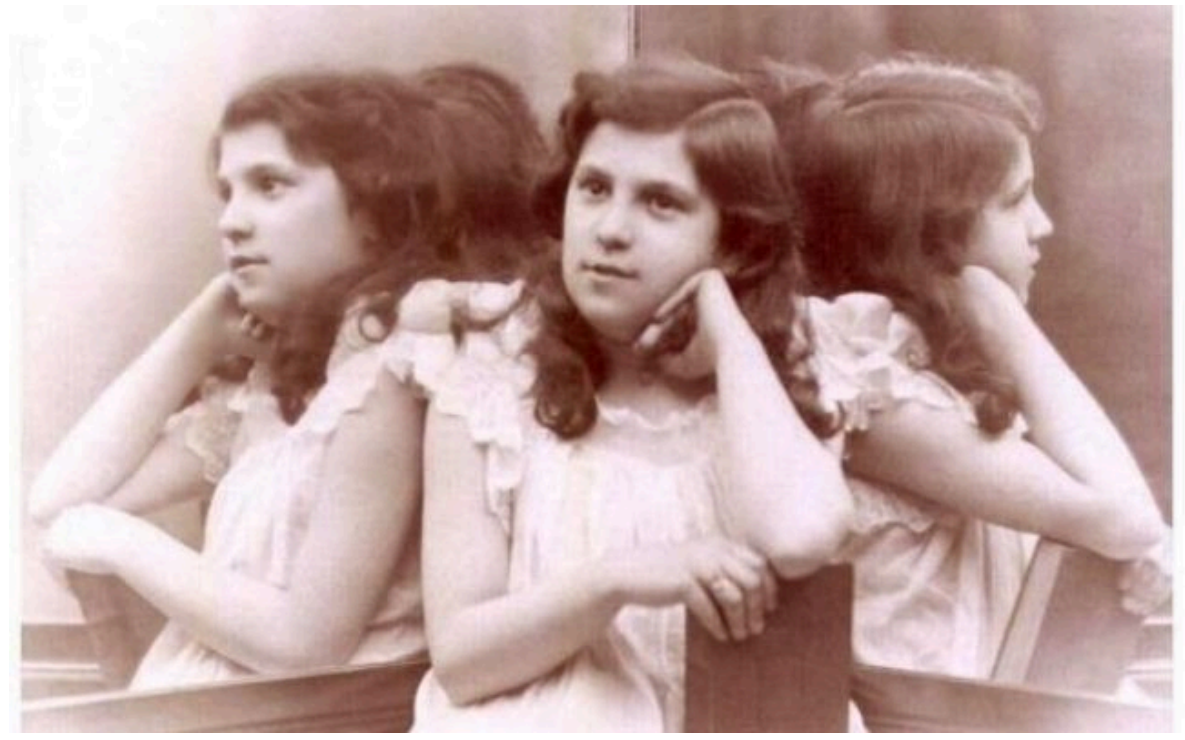

FIGURA 4.

Fotografía de F.E Musser (Harrisburg, PA, 1895*).

Colección Heinz-Werner Lawo 


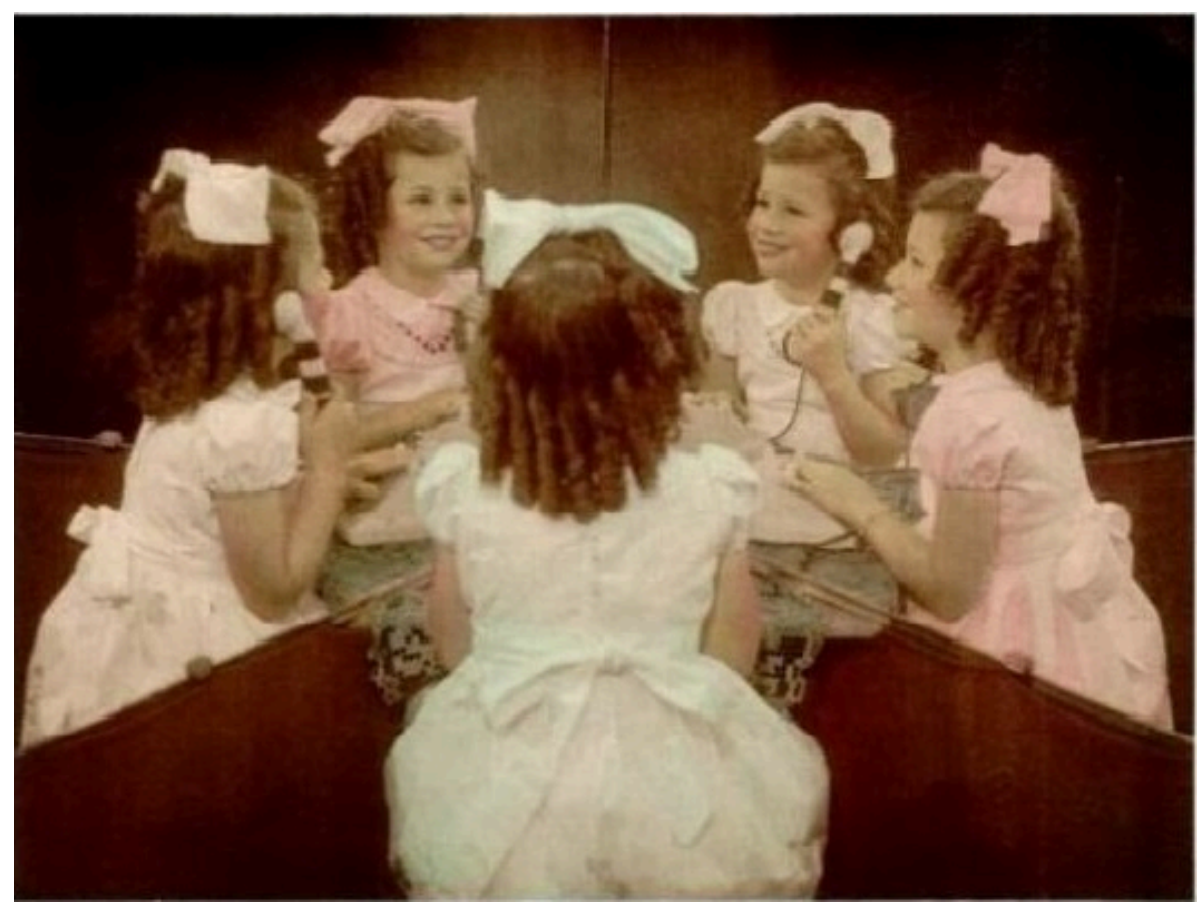

FIGURA 5.

Fotografía de H. Raffaelli $\left(1930^{*}\right)$.

Colección Heinz-Werner Lawo

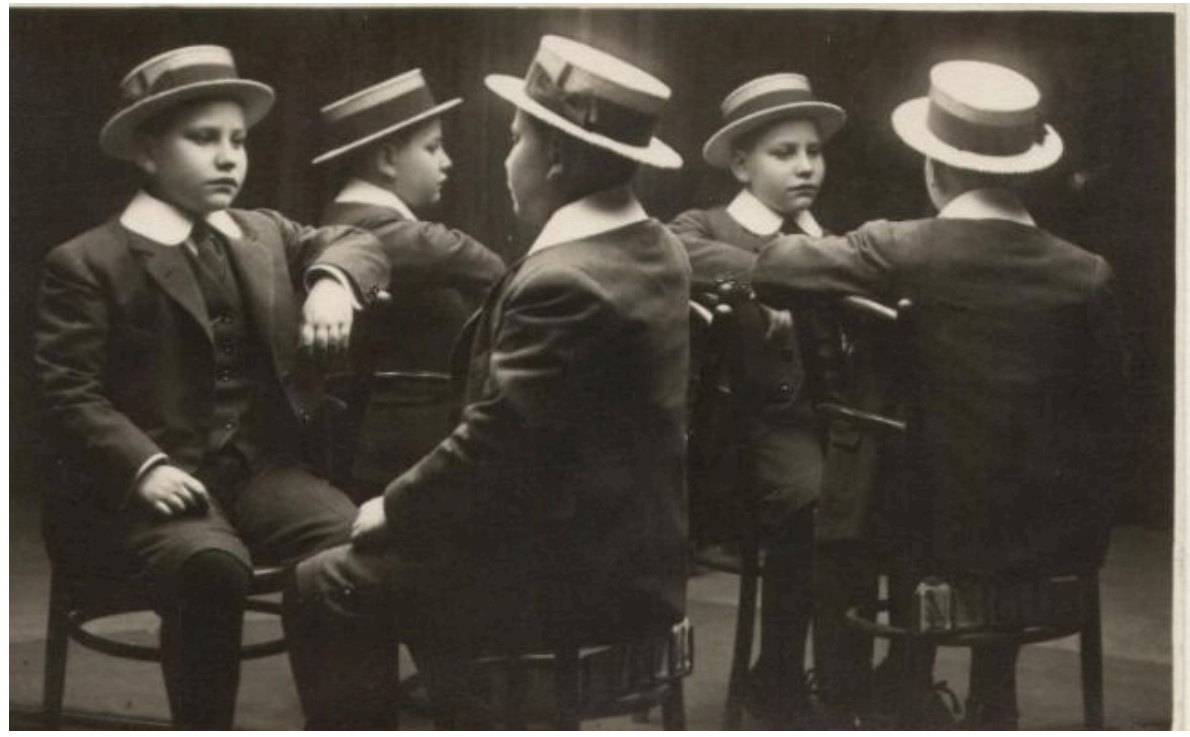

FIGURA 6.

Desconocido. (Madrid, España, 1917). “A mi mamaíta con un beso de su José Manuel 20-5-1917”. Colección Heinz-Werner Lawo 


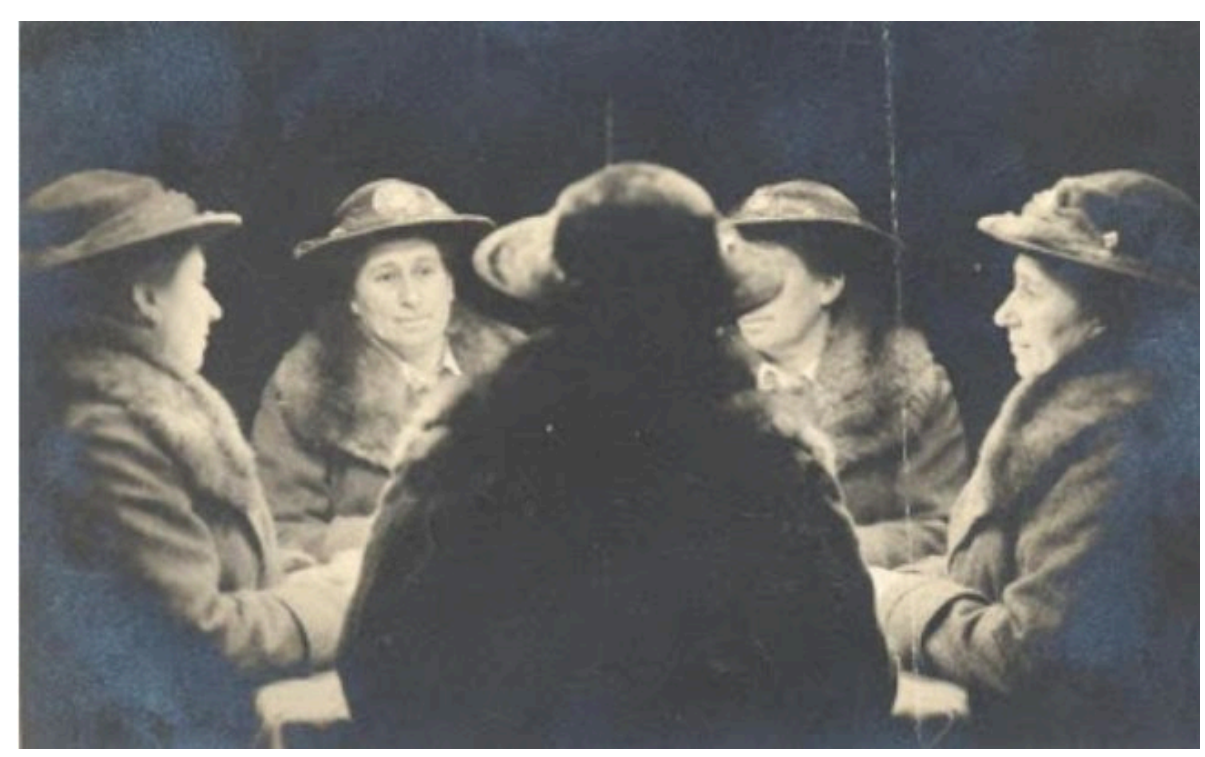

FIGURA 7.

Desconocido. (Wellington, Nueva, Zelanda, 1918*).

Cortesía de Horowhenua, Historical Society Inc

Se habrá notado que en una multifotografía la cámara debe posicionarse un par de metros detrás del fotografiado. Para obtener cinco perspectivas el ángulo de espejos debe ser de 72 grados, produciendo no sólo la multiplicación, también la desviación de miradas. El hecho de que la línea divisoria de los espejos contiguos no aparezca responde, seguramente, a fines estéticos; el fondo de la fotografía de Sam Auster es totalmente negro, pero en el resto de los ejemplos observamos que la presencia de los espejos es un elemento diegético fundamental. Como se quiera ver, justificaría aquello de la "penumbra que los rodea" y "la total inmovilidad de sus poses", como si la ocasión de la reunión hubiera sido una "sesión de espiritismo". No es azaroso tampoco el talante fantasmal que adjudica Auster a la fotografía: decíamos líneas arriba que el padre como cuenta pendiente regresa casi siempre a modo de espectro, de ahí que parezca que esté reunido con el solo propósito de autoinvocarse, "como si multiplicándose a sí mismo hubiera desparecido de forma accidental". Es justo suponer que tal proceso de multiplicación e invocación es la exploración ensayística que emprende "Retrato de un hombre invisible". Vemos que ninguno le regresa la mirada al otro. La mirada rebota entre los cinco. Se ha activado el juego especular. De laguna en laguna, la imagen unitaria del padre no es ya un asunto siquiera realizable; cada invocación lo fragmenta y lo multiplica. No por nada Auster declara que el proyecto le ocasiona una sensación de ahogamiento, y que el acto de escribir, en lugar de cicatrizar, abra la herida (Auster, 2012).

Si reparamos aún más en el desencuentro de miradas -"condenada(s) a seguir con la vista en el espacio [...], pero sin ver nada, incapaz de ver nada nunca” (pp.48-49)-, se refuerza una primera impresión en cuanto cada reflejo constituye una faceta inadvertida de la personalidad del padre (el padre bromista, el hombre de mundo, el parrandero, el casado, el soltero...). Resultaría sencillo ceder a la tentación de interpretarlo así, como si en la unión de piezas la imagen se completara. Aunque tal lectura no esté desprovista de fondo, parece fundamental observar dos asuntos al respecto: 1) aunque Auster se refiere a los reflejos como "varios yoes", la repetición de las imágenes no le representa otra cosa que la incertidumbre de su propio recuerdo; 2) para que la imagen se multiplique es necesario que Sam Auster esté de espaldas, es decir, que desaparezca, que se invisibilice; dicho de otra forma, que se omita para que puedan surgir al menos cuatro perspectivas de sí mismo. Si Sam Auster nos da la espalda no queda más que figurarnos el frente a través de sus repeticiones, pero no en función de reconstruir al modelo, en función de reconocer que en la simulación de cada Sam Auster habitan todos sus vestigios. Recordemos, están “invocando” el fantasma de Sam Auster; del hecho de que ninguno de los reflejos 
se miren podemos extraer la falta de correspondencia entre todos ellos. El recuerdo del padre está vacío, pero la suma de sus reflejos no se complementan entre sí. La materia prima de Auster son los fragmentos que no embonan y los recuerdos que no cuadran. Si, en el mejor de los casos, la relación entre literatura y fotografía se establece desde la perspectiva de la narrativa (Gutiérrez, 2013), lo que Auster descubre en la vanidad por intentar decir algo sobre alguien es, sin duda, "la anécdota como forma de conocimiento" (p. 91).

Todo lo anterior vale para apuntar otro vínculo específico. La fotografía de Sam Auster nos remonta casi en automático a otra de ellas tomada por lo menos veinte años antes. Nos referimos al famoso retrato múltiple de Marcel Duchamp de 1917 (ver Figura 8). Es común ya la concepción de fractura e inestabilidad que Duchamp confería a los retratos, sobre todo, en cuanto a la posterior gestación de sus alter egos. De acuerdo con James W. McManus (2008), el retrato fue tomado con fecha exacta el 21 de junio de 1917 en un estudio fotográfico de Nueva York. La sesión de fotos, que también incluyó a Francis Picabia y a Beatrice Woods, íntimos de Duchamp, más que un divertimento, invita a considerar el retrato como parte de la totalidad de su obra, específicamente, "en cuanto a la relación con los espejos, proporciones opuestas y cuestiones de identidad" (p. 126). Percibimos que la angulación en Duchamp es también la de los 72 grados, en donde experimentamos un efecto de desconcierto similar al de la foto de Sam Auster, es decir, que la distinción entre los objetos se extravía de momento; dicho retraso es lo que McManus denomina "la dialéctica creada entre la imagen fotografiada (en el espacio real) y los reflejos fotografiados del objeto (en el espacio virtual)" (p. 134). El efecto que se pretende es crear presencia donde, en teoría, no la hay, y donde los reflejos -la simulación del referente- son propensos a interpretarse particularmente. No es que la fotografía genere dobles, genera, por el contrario, metáforas (McManus, 2008), que no es lo mismo. ¿Son los reflejos referente del modelo o es el modelo referente de los objetos? Difícil decir. Ninguna probablemente. Cualquiera que sea el caso, el retrato de Duchamp rebasa por completo la noción de que pudo haberse tratado de un jugueteo pasajero, pero incluso asumiendo la naturaleza aparentemente trivial del acto, McManus sostiene que bien pudo haberse tratado de un readymade en formato imagen.

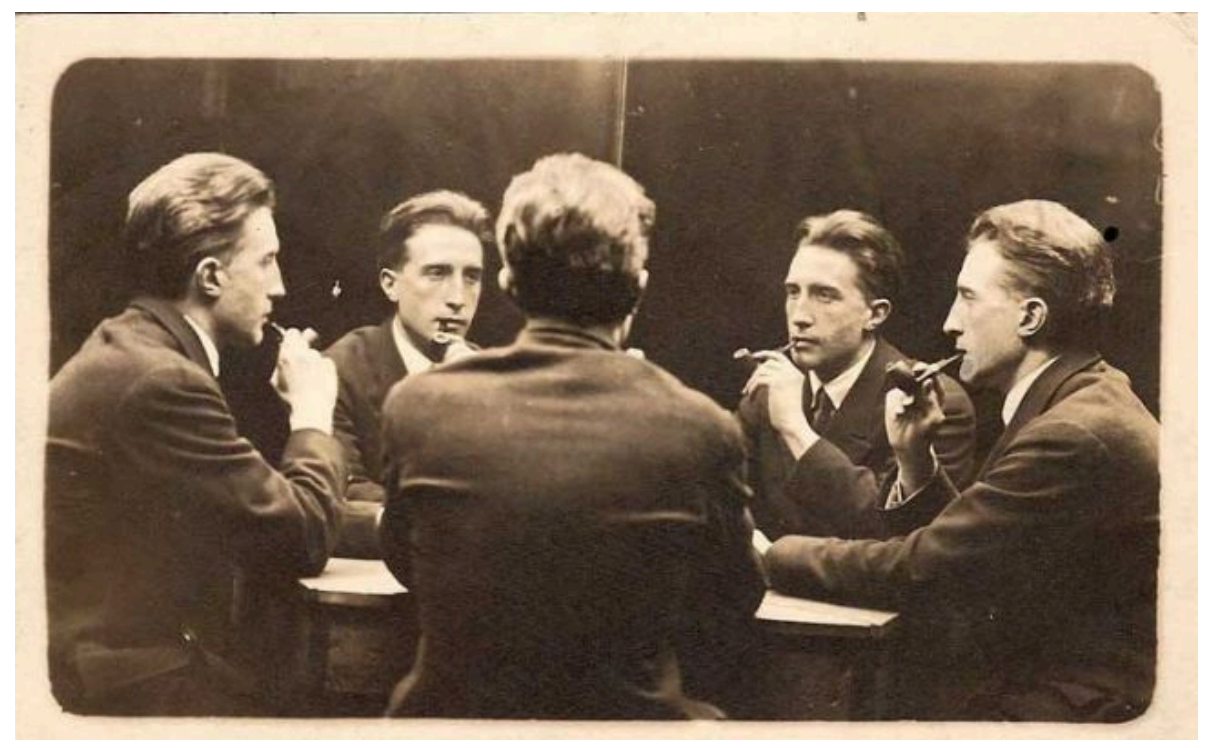

FIGURA 8.

Desconocido. (Broadway Photo Shop, NY, 1917). "Five-way Portrait of Marcel Duchamp”. Colección Centro Pompidou - Museo Nacional de Arte Moderno, París

Por otra parte, si acudimos nuevamente al texto de Reichstein, la autora nos advierte que retratos de este tipo no pasaron desapercibidos para otros artistas. Picabia y Henri Pierre Roché también cuentan con una multifotografía en 1917, pero en años previos el arquitecto, músico y fotógrafo polaco Waclaw Szpakowski en 1912 y el pintor, escritor y filósofo Stanislaw Ignacy Witkiewicz -polaco también- en 1916 
habían emprendido proyectos similares. A diferencia de Sam Auster, donde la mirada, digamos, está puesta en todas partes, Szpakowski tiene el hombro derecho metido ligeramente en dirección a la mesa, provocando que el resto del torso se incline hacia el lado contrario; este contraste, pequeño pero sustancial, genera que todos los reflejos estén atentos a sí mismos, incluso hasta con el espectador de la fotografía. En el retrato de Szpakowski (ver Figura 9) apreciamos de inmediato cómo el reflejo que está en frente a la derecha del modelo nos dirige la mirada y cómo el resto de los reflejos miran a este fijamente activando el juego especular. Por otra parte, Witkiewicz (ver Figura 10) se retrata vestido con el uniforme del ejército zarista. De gesto duro, suspicaz, como quien resiste un interrogatorio, el retrato fue tomado en San Petesburgo durante la Primera Guerra Mundial, años en que Witkiewicz formaba parte de la infantería rusa. Szpakowski murió en 1973, todo parece indicar que la fotografía referida no cuenta con mayores resonancias en el resto de su obra. Witkiewicz se suicidó en 1939, al menos en su obra pictórica la presencia del primer plano es evidente.

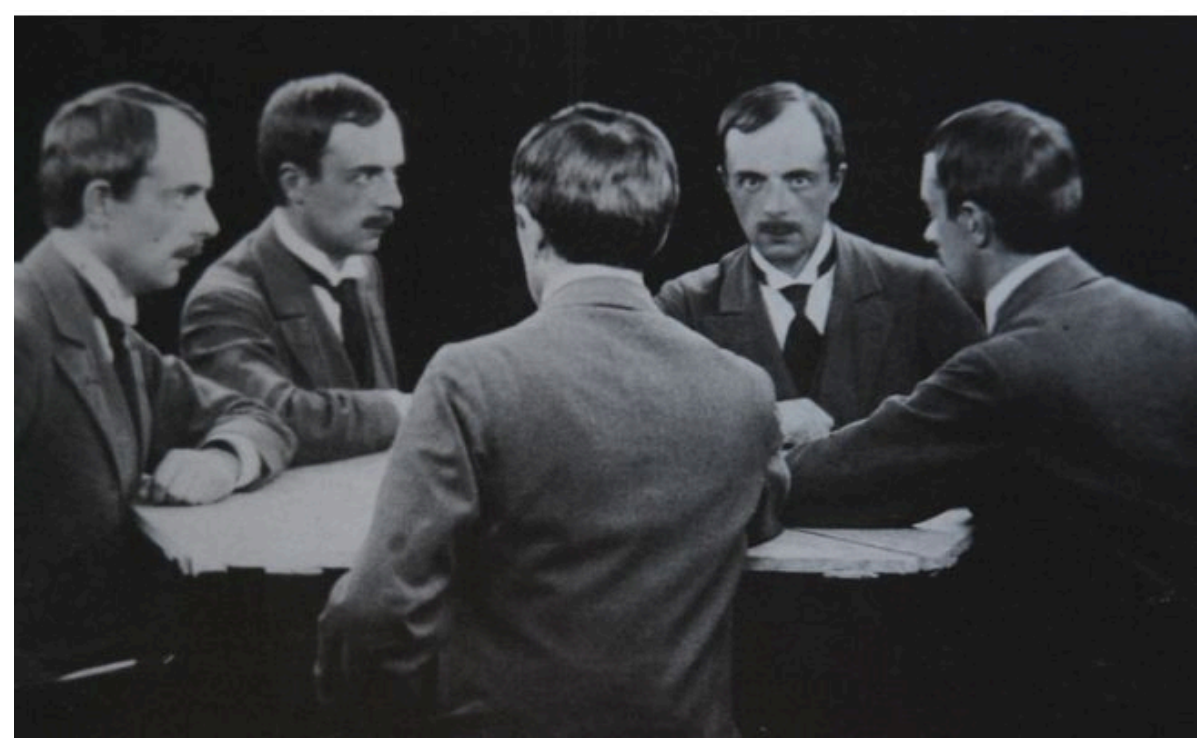

FIGURA 9.

Desconocido. (1912). Multiple self-portrait, Waclaw Szpakowski 


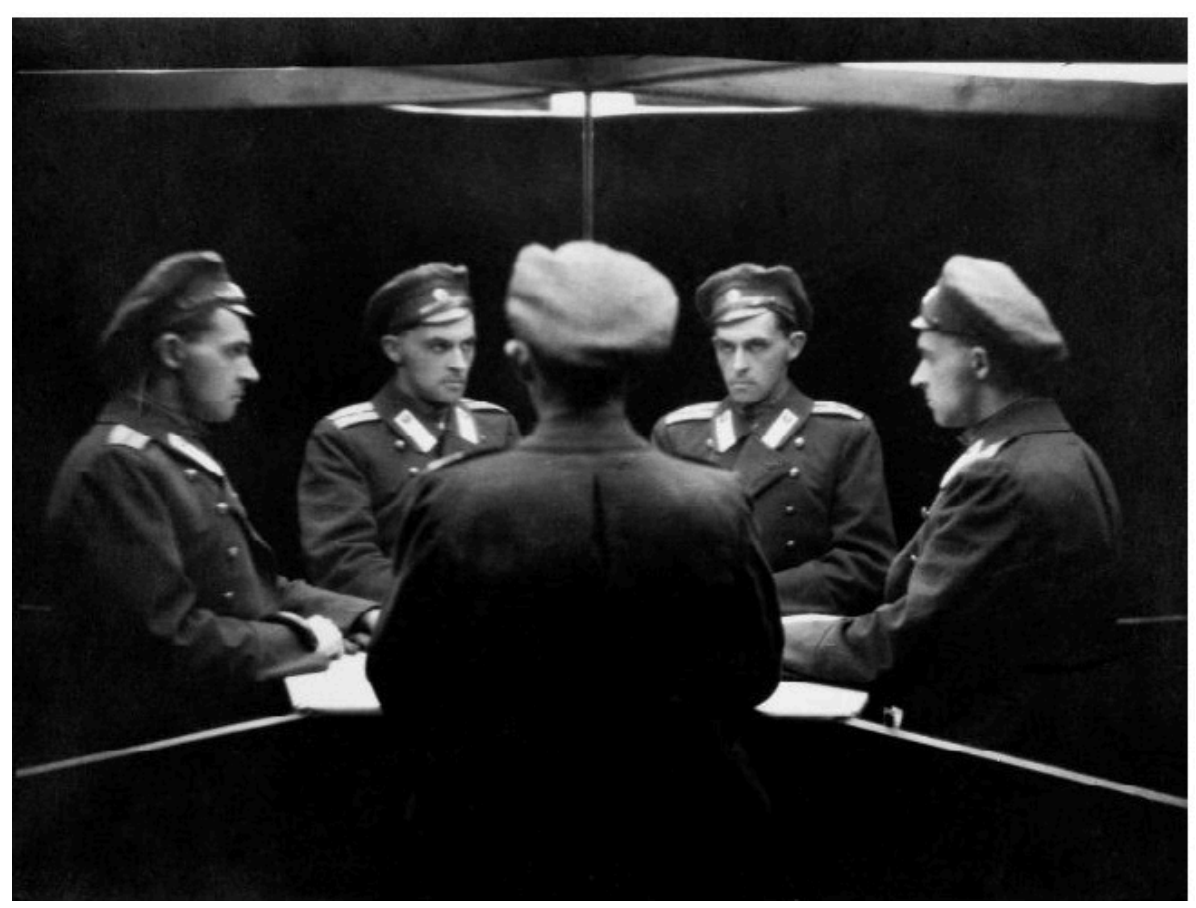

FIGURA 10.

Desconocido (San Petesburgo, Rusia, 1917). Multiple self-portait in mirrors, Stanislaw Ignacy Witkiewicz

Habría un antecedente más, el de Umberto Boccione de 1905-1907 (ver Figura 11). De acuerdo con Reichstein, el retrato de Boccione se circunscribe al futurismo italiano dado que el truco fotográfico subvierte el sentido usual adjudicado a la fotografía, capturando la realidad de manera ambigua a condición de quebrantarla. De ahí que Boccione agregue en los márgenes los pronombres “io" y "noi” (yo y nosotros en italiano) como una suerte de título, como si en el acto de multiplicarse se confrontara la pluralidad del ser (Reichstein, 2007). La ubicación de los pronombres tampoco es casualidad: partiendo de la simpatía futurista por la geometría y sugiriendo probablemente la aplicación de una fórmula matemática, el yo se encuentra justo encima del modelo y el nosotros en el margen derecho. Lo anterior basta para apuntar que la fotografía múltiple, como suvenir o representación vanguardista, se pensó como instrumento tecnológico para engañar al ojo, según Davis todo con el propósito, voluntario o no, de asentar la idea que la estética fotográfica comienza en realismo pero termina en mistificación (citado en Reichstein, 2007), pero a este punto volveremos más adelante. 


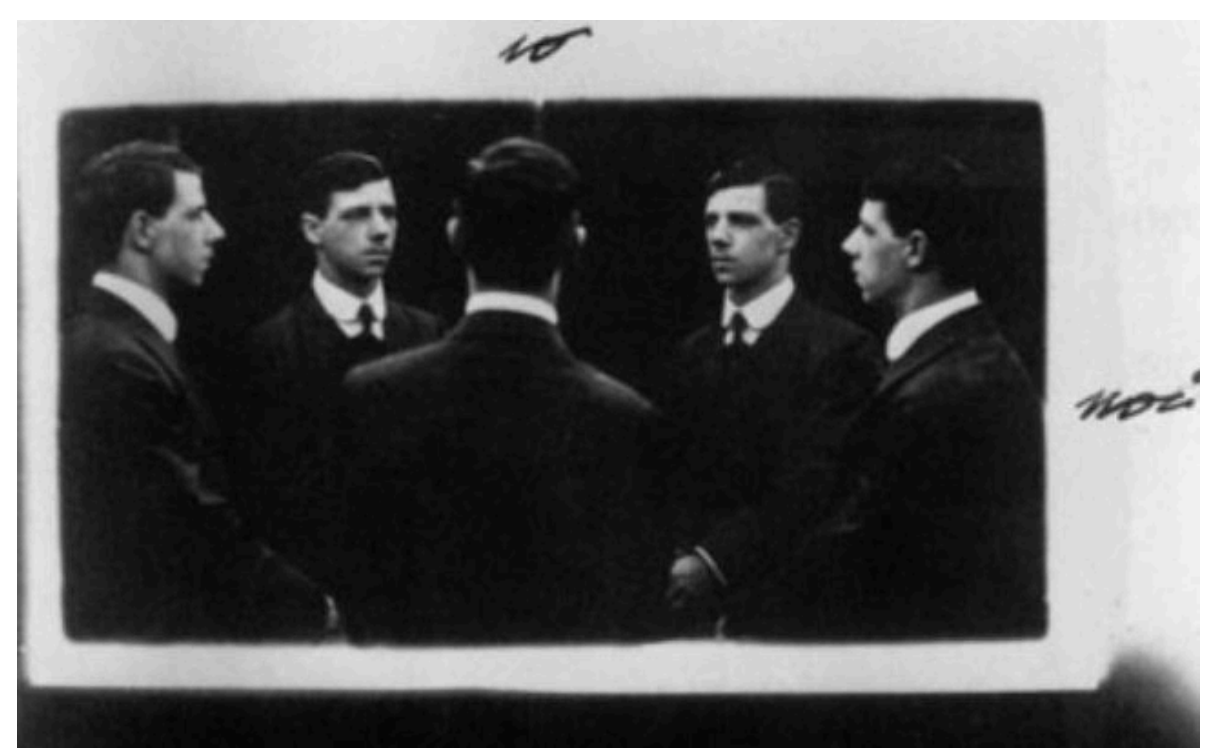

FIGURA 11.

Desconocido (1905-1907*). Umberto Boccioni

\subsection{De la apariencia a la aparición: resignificar la experiencia a través de la escritura ensayística y la multifotografía}

Ahora bien: con lo anterior no queremos asentar que Sam Auster tuviera en mente a Duchamp al momento de retratarse, asunto que ni siquiera podríamos probar, pero, ¿̇abría, en cambio, Paul Auster, de la existencia de las fotos de Duchamp, Szpakowski, Witkiewiz y Boccione o del renovado advenimiento de la fotografía múltiple a finales de los treinta? Para el fotógrafo tabasqueño Francisco Cubas (2013) es poco probable puesto que es "imposible que lo hubiera sabido sin haberlo mencionado" (párr. 3). En efecto, no existe una alusión -una explícita por lo menos- en el libro aquí referido, pero de ningún modo significa que Auster hijo no estuviera familiarizado ni con la obra ni con la trayectoria de los artistas antes mencionados. Sabemos, de entrada, que los apellidos Picabia, Duchamp y Roché aparecen en "Los poemas y los días" (Auster, 1996), ensayo sobre la influencia recíproca entre la lengua inglesa y francesa en el que dedica, por cierto, un minucioso comentario a la época de vanguardias. Ese mismo ensayo es ilustrado con retratos de Man Ray (seudónimo de Emmanuel Radnitzky), reconocido protagonista de vanguardias y amigo de Duchamp y Picabia. Considerando este factor, es al menos concebible que Paul Auster reconociera una correspondencia entre lo que Duchamp intentó hacer con la fotografía y lo que él quiso hacer con su libro.

Cabe aclarar que de ser cierta dicha inferencia, el hilo que los une apunta en dos direcciones más. Nos referimos a la cronofotografía y a los conceptos apariencia y aparición. De origen científico, la cronofotografía capturaba el movimiento en una secuencia de imágenes grabados en pequeños marcos (ver Figuras 12 y 13). Predecesor del cine, la cronofotografía, apropiada por las vanguardias, se usó para detener o retrasar el tiempo; dicho de otra manera, para descomponerlo en factores. En 1912 Duchamp pintó Desnudo bajando la escalera, clara alusión no solo a los experimentos de Étienne-Jules Marey -inventor- sino también al movimiento de nuestra mirada que, de imagen en imagen, persigue el lugar del referente (McManus, 2008). 


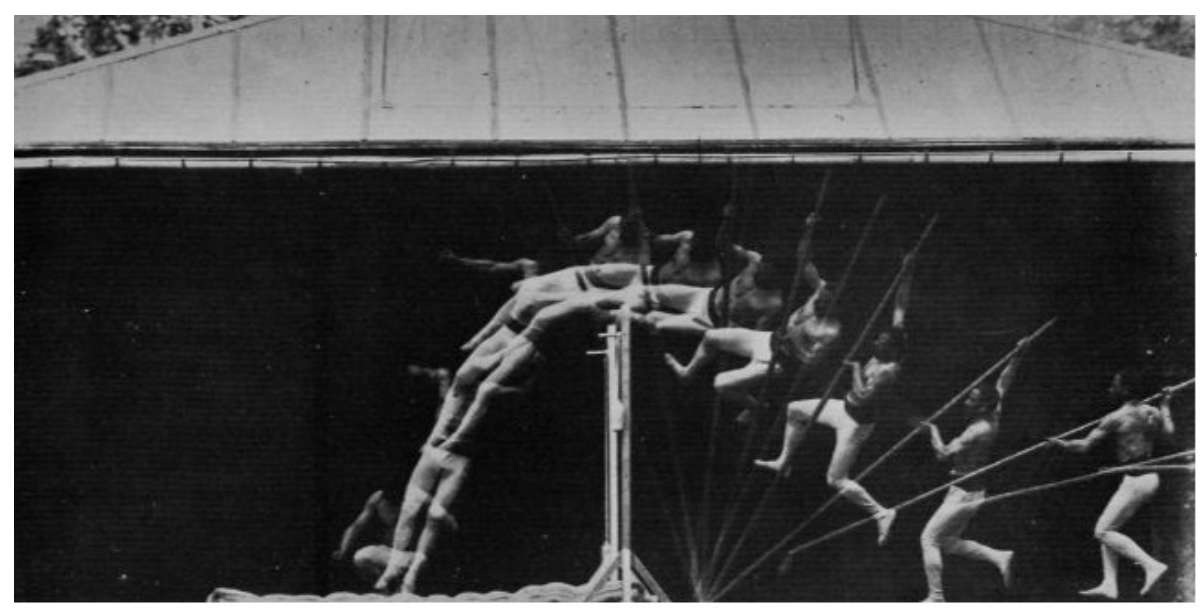

FIGURA 12.

Cronofotografía de Etienne-Jules Marey (1890-1891*).

Chronophotographie d'un homme sautant à la perche

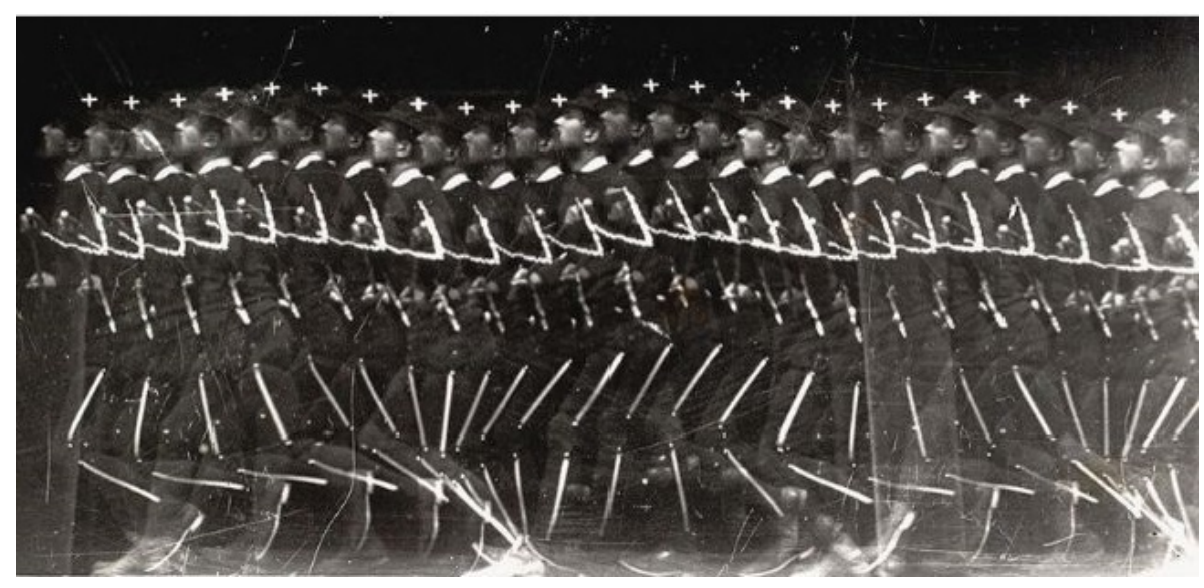

FIGURA 13.

Cronofotografía de Etienne-Jules Marey (1886).

Homme segment / course d'un dompteur de lion

En segundo término, hacia 1915, dos años antes de su retrato múltiple, Duchamp exploraba la forma en que una expresión visual podría transferirse al lenguaje, es decir, al igual que con los ideogramas chinos se interesó en el proceso de significación que va del lenguaje al ícono y del ícono a la palabra nuevamente (McManus, 2008). En este sentido, resulta necesario destacar que en $A$ l'Infinitif -las notas escritas por Duchamp entre 1914 y 1923 , en las que comenta su propio retrato múltiple- apuntaba lo siguiente: la apariencia es la suma de la evidencia sensorial, lo que permite la percepción ordinaria del objeto; la aparición es su molde. Octavio Paz (2008), en su estudio sobre Duchamp, lo explica de la siguiente manera: "La apariencia es la forma momentánea de la aparición. Es la forma que aprehendemos con los sentidos y se disipa a través de ellos. La aparición no es una forma sino una conjunción de fuerzas, un nudo" (p. 186). A decir de Paz, Duchamp se propuso hacer un arte de apariciones y no de apariencias, "una obra que apostara por la realidad invisible, es decir, de relaciones, esencias y signos" (p. 140). En otras palabras, "el signo debe ser aislado para llegar a la aparición de la verdad, de la idea, y no quedarse en una mera apariencia de la obra de arte” (López, 2006, p. 331).

El paso de la apariencia a la aparición es de profundidad, es decir, creadora de sentido y resignificadora de la experiencia. Antes que un modo de apreciación, ambos conceptos se entrelazan para hacer surgir un contenido en apariencia velado. En este sentido, una fotografía es un suvenir y también es la representación de 
la invisibilidad de un sujeto que se retrata mostrándonos la nuca. La idea aparece a condición de que la lectura de la obra no se atenga a su molde. Por otra parte, la metáfora de la realidad invisible tampoco debe dejarse de lado: en 1978 la editorial Arcade Publishing publica una traducción de Apariencia desnuda. La obra de Marcel Duchamp de Octavio Paz, el estudio que hizo sobre artista y que aquí hemos citado; en 1979, Auster nombra "retrato de un hombre invisible" a la fotografía de su padre. Si bien la resonancia podría ser mera casualidad, es por demás presumible que de haber conocido Auster el libro de Paz, se hubiera interesado en él.

Es bajo estas coordenadas que parece justo postular que en "Retrato de un hombre invisible" se está jugando algo más que un duelo, tal como suele pensarse más temprano que tarde. Lo que queremos decir, al fin y al cabo, es que es absurdo pensar que Auster no conociera la fotografía de Duchamp ni el resto de los retratos múltiples de algunos vanguardistas. Es razonable que el juego especular de miradas, en donde el referente está en movimiento, encuentre cierto eco en la influencia que la cronofotografía tuvo en Duch asimismo, que los conceptos de aparición y apariencia sean de una u otra manera, para bien o para mal, llevados hasta sus últimas consecuencias en el entendimiento que Auster tuvo sobre la postal de su padre, es decir, en cuanto a que si se quebranta la superficialidad de la obra (su apariencia), esta nos conduce a un lugar más allá de un simple rompecabezas (su aparición). Suele olvidarse, aunque se repita hasta el hartazgo, que resignificar la experiencia es un tópico ensayístico en sí mismo y que en el caso de "Retrato de un hombre invisible", el padre como cuenta pendiente es la idea que pervive independiente del molde.

Antes de terminar, debemos reparar lo dicho por Douglas Davis en la introducción de Photography as Fine Art: mientras que es por demás probable que la mayoría de las fotografías múltiples no tuvieran como objetivo revolucionar el arte, acaso el encanto radicaba en la transición que suponían del realismo a la mistificación (citado en Reichstein, 2007. Si comprendemos mistificar en su segunda acepción -o sea como el acto de enmascarar lo que está ocurriendo, ya se trate de una experiencia, de una acción o de un proceso (Laing, 1976), y no, en cambio, como la sustitución de una interpretación verdadera por otra falsa (misma que arrastraría una connotación de embaucamiento)-, hallamos las condiciones para que el movimiento hacia la mistificación sea el efecto de perspectivas que consigue el memoir que ensaya desde la multifotografía; cuando tal demora de sentido se armoniza con una vida que ya no es la nuestra, el recuerdo difuso y la anécdota conjeturada operan en provecho de la escritura.

En Experimentos con la verdad (2003) Auster ha dicho que para escribir sobre sí mismo debía tratarse como si fuera otro (p. 150). Tomando prestada la famosísima frase de Rimbaud, para pensar en uno mismo uno debe de convertirse en alguien más. Esto, antes que un rodeo, se convierte en poética: lo que en apariencia es la vida de un hombre, se convierte en realidad en un ensayo sobre "la factibilidad de que una persona hable sobre otra” (p.180). En este sentido, vale la pena interrogar el texto de Auster a partir de las pistas esbozadas en este trabajo (pistas minúsculas, si se quiere, pero estimulantes). Nos referimos a comprender al memoir como una clase de texto imaginativo antes que (auto)biográfico, como texto que linda con el ensayo cuando opera bajo la lógica del pensamiento retrospectivo, sobre todo cuando recordar se parece cada vez más a inventar.

\section{A MODO DE CONCLUSIóN}

En síntesis, podríamos resumir nuestro artículo en los siguientes puntos consecuentes: 1) Ensayo y memoir son dos escrituras cercanas en sí, puesto que ambas presentan cierta propensión por la reminiscencia, en algunos casos la laguna biográfica se completa con imaginación, lo cual tiene por consecuencia retoques, modificaciones, dramatizaciones, exageraciones, ocultamientos, revelaciones, camuflajes y, ahora con "Retrato de un hombre invisible" de Paul Auster, un juego de perspectivas como metáfora ficcional. 2) El concepto de la doble perspectiva -es decir: el análisis del significado de la experiencia a partir de dos voces, una poco confiable que recuerda (Yo-narrador) y otra sofisticada, sabia, más sensata, que lo mira todo en retrospectiva (voz narrativa) y valora lo recordado- pone en marcha un tipo de escritura en donde el autor está separado de su instancia de enunciación, en donde la especulación, que es una forma de la ficción, torna 
el estado permanente del pensamiento retrospectivo. 3) En "Retrato de un hombre invisible" se juega algo más que duelo: mientras que Paul Auster intenta advertir de su padre recientemente fallecido, al mismo tiempo va componiendo una metáfora de su ausencia que tiene como base una fotografía; en otras palabras, la multifotografía de Sam Auster como el artificio de vinculación entre ensayo, memoria y ficción, condición para que de la mistificación del objeto -el recuerdo difuso, la anécdota conjeturada...- advenga un ensayo sobre la muerte.

En pos de establecer una vinculación entre la ensayística ficcional -fusión entre ensayo y ficción-y el memoir como escrituras retrospectivas -esto es: escrituras que reconocen plenamente que su materia de trabajo es la reconstrucción de uno o varios episodios del pasado-, fue preciso mostrar que, si de memoria se trata, ambas tienden a la imaginación toda vez que recordar va pareciéndose cada vez más a inventar. A su vez, quisimos subrayar de manera constante que es insuficiente limitarnos a señalar que ensayo, memoria y ficción se entrelazan sino decimos cómo es que dicho fenómeno acontece. Por este motivo, y puesto que sin ejemplos nada podemos probar, fue necesario hacer mención de la estrategia que creemos subyace a "Retrato de un hombre invisible" de Paul Auster. Esperamos que el resultado de haber hecho este rodeo marque la pauta, al menos, para hacer tambalear algunos atavismos, por ejemplo, que el ensayo es estrictamente prosa no ficcional, que la valoración de un memoir dependa de su "alto" o "bajo" grado de ficcionalidad, pero, sobre todo, que el pensamiento retrospectivo cuando de un difunto se trata entrañe exclusivamente un duelo por escrito.

Acostumbrados, como hemos estado, a concebir ensayo y ficción como mutuamente excluyentes, la poca teoría sobre el ensayo que existe se enfoca únicamente en el análisis de contenido descuidando la forma y estrategia literaria. El investigador, no ya de la obra de Paul Auster, sino del ensayo como género y como forma, no debe limitarse a tremenda ociosidad de descubrir ficción donde supuestamente no debería haberla, por el contrario, es necesario, al menos, describir la manera en que la ficción se comporta en tal o cual texto, cómo se manifiesta, qué consigue y qué revela de la literatura, para qué está ahí y si reformula nuestra experiencia y concepción ensayística.

Será necesario también un estudio de mayor profundidad sobre los rastros de las vanguardias en la obra de Auster. Por lo menos aquí dicha empresa nos rebasa. Nuestro estudio se restringe a mostrar un modo en que puede presentarse la ensayística ficcional, es decir, a través de cierto uso del memoir como clase de escrito propenso al contubernio entre ensayo y ficción. Subrayamos aquella clase de memorias que no permanecen estrictamente bajo la premisa de reconstruirse a uno mismo y, por el contrario, ponderan la especulación imaginativa por encima de una verdad naturalista. Lo que se pretende, allende de la reconstrucción del sujeto modelo, es inventar al retratado y, posteriormente, ensayar, quizá, la idea que permea el recuerdo del objeto evocado (la infancia, la muerte, la enfermedad, una ciudad...).

\section{REFERENCIAS}

Asensi, M. (2016). Teoría de los modelos de mundo y teoría de los mundos posibles. Actio Nova: Revista de teoría de la literatura y literatura comparada (0), 38-55.

Auster, P. (1996). Los poemas y los días. Fractal, 1(1), 83-124.

Auster, P. (2003). Experimentos con la verdad. España: Anagrama.

Auster, P. (2012). Retrato de un hombre invisible. En P. Auster, La invención de la soledad (pp. 11-101). México: Booket Planeta.

Barnes, J. (2010). Nada que temer. España: Anagrama.

Baudrillard, J. (1978). Cultura y simulacro. A. Vicens y P. Rovira (Trads.). Barcelona: Kariós.

Crum, M. (28 de septiembre de 2015). Nothing but the truth?: On lying and memoir-writing. The Huffington Post. Recuperado de https://bit.ly/38jQekQ 
Cubas, F. (19 de febrero de 2013). La plural soledad del retrato múltiple. El Fotógrafo Lector. Recuperado de https:// bit.ly/36fUwaT

Deleuze, G. (1989). Lógica del sentido. Barcelona: Paidós.

Fass, P. S. (2006). The Memoir Problem. Reviews in American History, 34(1), 107-123. Recuperado de https://bit.l $\mathrm{y} / 2 \mathrm{rcM} 3 \mathrm{Xm}$

Godínez, A. (28 de junio de 2015). Figuras del padre. El padre, origen y destino del hijo. Replicante. Recuperado de h ttps://revistareplicante.com/figuras-del-padre/

González, T. (2019). La escuela del aburrimiento o los límites del ensayo. Ficción y reflexión en la escritura de Luigi Amara. En M. Kunz y C. Mondragón (Eds.), Nuevas narrativas mexicanas 3. Escrituras en transformación (pp. 9-23). España: Linkgua Ediciones S.L.

Gutiérrez, C. (2013). La fotografía como recurso en la literatura. Academia. Recuperado de https://bit.ly/34XXOiV Hitchens, C. (2013). Hitch-22. Confesiones y contradicciones. España: De Bolsillo.

Laing, R. D. (1976). Mistificación, confusión y conflicto. En R. Laing, La otra locura (pp. 397-418). España: Tusquets. Recuperado de https://bit.ly/2qxiljw

Lopate, P. (2005). Reflection and retrospection: a pedagogic mystery story. Fourth Genre: Explorations in Nonfiction, 143-156. Recuperado de https://bit.ly/2qx7guw

Lopate, P. (2013). To show and tell. Estados Unidos: Free Press.

López, E. (2006). Poder, tradición e historia del arte: Apariencia desnuda. La obra de Marcel Duchamp. Anales de Historia del Arte, 16, 315-338. Recuperado de https://bit.ly/2LyPCxM

McManus, J. W. (2008). Mirrors, TRANS/formation and Slippage in the Five-Way Portrait of Marcel Duchamp. The Space between, IV(1), 125-148. Recuperado de https://bit.ly/2s847ld

Paz, O. (2008). Apariencia desnuda. La obra de Marcel Duchamp. México: Era.

Reichstein, I. (2007). A multigraph from Montreal. Photographic Canadiana, 33(1), 12-17. Recuperado de http://w ww.phsc.ca/reichstein/multigraph_article.pdf

Roth, P. (2007). Patrimonio. España: Seix Barral.

Schwartz, M. (1998). Memoir? Fiction? Where's the line? Creative Nonfiction, (10), 338-343. Recuperado de https ://bit.ly/38j4iLt

Weinberg, L. (2012). El ensayo y la buena fe. En D. Vandebosch, D. Castilleja y E. H. Houvenaghel (Eds.), El ensayo hispánico: cruces de géneros, sintesis de formas (pp. 21-46). España: Librairie Droz.

Yehya, N. (14 de mayo de 2015). Entrevista con Phillip Lopate. Letras Libres. Recuperado de https://www.letraslibr es.com/mexico-espana/entrevista-phillip-lopate

\section{Notas}

1 El presente documento es un extracto de la tesis doctoral Derivas del ensayo contemporáneo: aproximación a la ensayistica ficcional, misma que se lleva a cabo dentro del Doctorado en Humanidades (2016-2020) de la Universidad de Guadalajara.

2 A la fusión entre ensayo y ficción he dado el nombre de ensayistica ficcional, es decir: aquel tipo de escritura reconocible y asociable al ensayo que va dotándose de artilugios ficcionales para su composición. Dicho concepto intenta debatir la consabida idea de que ensayo y ficción son términos mutuamente excluyentes. La ensayística ficcional no circunscribe un mundo posible a la usanza de la teoría ficcional clásica, por el contrario, se adhiere a la teoría de modelo de mundo establecida por Asensi (2016) y a las nociones de simulacro de Baudrillard (1978) y Deleuze (1989). Este tema lo trato a detalle en "La ensayística ficcional a examen", artículo publicado en el 2018 dentro del libro Las humanidades hoy. Miradas, recorridos y aproximaciones de la Unviersidad de Guadalajara, en el que, en otras cosas, propongo a Montaigne como un autor propenso a las ficciones y analizo la relación entre ensayo y buena fe.

3. En el original se lee asi: “....and therefore the narrator would know things the I-character didn't; that all of nonfiction is an imaginative shaping of facts into a pointed narrative, and distorts or lies by being highly selective, its object being to attain a sense of literary, not literal, truth...”. 
4. En el original se lee así: "Recently, on a visit to Mexico, I had a conversation with two bright, young, philosophically trained Mexican essayists about the nature of the essay. The maintained that the personal essay, at least, should be classified as fiction - because the narrating self is a construction, because memory is unreliable and relies on imagination to fill in the gaps, and because many of the assertions in a personal essay cannot be tested or proven true. [...] But I held out for the idea that nonfiction, including personal essays, has a relationship to factual reality and self-testimony that makes it fundamentally different from fiction."

5. La naturaleza del ensayo se discutió con cierto rigor en la prensa mexicana durante el verano del 2011, primero en la revista Luvina de la Universidad de Guadalajara y posteriormente en los blogs y columnas periodísticas de los involucrados. En estas líneas no reviviremos los pormenores del debate. Remito a la lectura completa de los ensayos "El ensayo ensayo" (Letras Libres, febrero 2012, núm. 158, pp. 22-27), "Ráfagas sobre el ensayo" (Letras Libres, mayo 2012, núm. 161, pp. 94-95) y "Un ensayo es un ensayo es un ensayo” (Laberinto, núm. 455, 3-VI-2012), todos ellos de Luigi Amara.

6. La postura de Amara recibió respuesta del escritor y crítico Rafael Lemus, quien lo invitaba a abandonar "regla y tijeras" y pensar el ensayo como práctica escritural diversa. Esto es: no hay ensayo y no hay género, lo que hay son escrituras con rasgos particulares que tendrían que analizarse una a una. Lemus objetaba que la división de Amara era reduccionista e inoperable, aduciendo, no sin cierta sorna, que de seguir así deberíamos pensar también en el cuento-cuento, poema-poema, novela-novela. Para un informe más detallado remito directamente a la lectura de "El ensayo como práctica” (Letras Libres, abril 2012, núm. 160, pp. 91-93) de Rafael Lemus y a "Ilusiones del ensayo-ensayo” y “Yo acuso! (al ensayo) (y lo hago)" de Heriberto Yépez, estos últimos localizables en su página web www.archivohache.blogspot.mx, actualmente descontinuada.

7 Las Figuras 2, 3, 4, 5, 6, 7 son extraídas del blog Uneinsamkeiten/Unsolitudes a cargo de Heinz-Werner Lawo. Se especifica, en la medida lo posible, autor, año, lugar, título y colección. Los años que son aproximados se marcan con un asterisco.

Todos los derechos reservados. Universidad de Costa Rica. Esta revista se encuentra licenciada con Creative Commons. Reconocimiento-NoComercial-SinObraDerivada 3.0 Costa Rica. Correo electrónico: humanidades@ucr.ac.cr/Sitioweb: http: //revistas.ucr.ac.cr/index.php/humanidades CC BY-NC-ND 